\title{
ANALISA PERKEMBANGAN DAN KEARIFAN TEMPATAN: KARYA FIQH MELAYU KLASIK
}

\section{Analysis of Development and Local Wisdom Classical Malay Fiqh Works}

\author{
Mohd Puaad Abdul Malik* \\ Faisal@Ahmad Faisal Abdul Hamid** \\ Rahimin Affandi Abd Rahim***
}

\begin{abstract}
This article focusses on the subject of classical Malay fiqh works which are intellectual works of Malay Muslim scholars in various Islamic legal topics whether 'ibadāt, mu' āmalāt, munākahāt and others. These works play important roles in the Malay community as a means of communication, knowledge, and scientific development. This article analyzes the historical development of classical Malay figh works to present the concept of local wisdom based on Islamic Malay literature. The method of analysis used
\end{abstract}

* Ph.D Candidate, Department of Islamic History and Civilization, Academy of Islamic Studies, University of Malaya, Kuala Lumpur. puaadmalik@siswa.um.edu.my

** Senior Lecturer, Department of Islamic History and Civilization, Academy of Islamic Studies, University of Malaya, Kuala Lumpur. faisal@um.edu.my

*** Associate Professor, Department of Fiqh and usul Fiqh, Academy of Islamic Studies, University of Malaya, Kuala Lumpur. faqir_ila_ rabbih@um.edu.my 
is historiography that examines the development of an idea. Facts obtained will be thoroughly screened using the Malay induction history approach. Discussion from the intellectual aspect shows that Malay fiqh works are the result of the Malay Muslim local wisdom. Those works are unique in their identity as a means of understanding and developing knowledge in the Malay world. They also brought a dynamic change to intellectual development in the Malay world and in conformity with the teachings and practice of Islam. They are also not stereotype in nature but high in value and quality.

Keywords: Malay fiqh works, Malay world, Islam, Malay society

\section{PENDAHULUAN}

Tempoh semenjak abad ke-17 hingga awal abad ke-19 banyak melahirkan asas-asas intelektualiti yang cemerlang melalui pelbagai karya yang tahan zaman. ${ }^{1}$ Kebanyakan karya-karya ini belum dikaji secara menyeluruh dan diteliti, baik dalam lingkungan sejarah dunia Melayu mahupun dalam dinamika wacana intelektual. Berasaskan kepada kenyataan di atas, permis penulisan ini akan menerokai perkembangan penulisan karya fiqh Melayu klasik. Asas kajian ini adalah meneliti ciri dan idea penulisan serta kearifan tempatan dalam karya fiqh Melayu yang digarap oleh pengarang karya fiqh mengikut corak dan pola penulisan Melayu klasik. Justeru, dalam meneliti eksplorasi dan

Antara contoh penulisan yang boleh nyatakan seperti penulisan oleh S.M. Naquib al-Attas, Preliminary Statement on A General Theory of the Islamization of the Malay-Indonesian Archipelago yang menjelaskan era Alam Melayu suatu era yang penting dalam sejarah perkembangan intelektual Islam di Alam Melayu; Abdul Kadir Haji Muhammad, Sejarah Penulisan Hukum Islam di Malaysia (Kuala Lumpur: Pustaka Salam, 1996), 22; Abd. Jalil Borhan, "Sejarah Awal Penulisan dan Perlaksanaan Hukum Islam di Alam Melayu," Jurnal Syariah (1993), 146-152; Wahidah, "Studi Naskah Fikih Melayu (Risalah Is'af al-Raghibin fi 'Ilmi al-Faraidh) karya Jad Ahmad Mubarak," AL-BANJARI vol. 19, no. 1 (2019), 25-48. 
kronologi perkembangan karya fiqh Melayu perlu berhati-hati, bersikap apologatik dan menilai sesuatu perkembangan silam dari konteks zamannya. ${ }^{2}$ Selain itu, bagi memahami proses perkembangan intektual ia mesti merujuk kepada ketulenan karya-karya asli agar kemampuan dan daya sesuatu karya itu dapat diterjemahkan dari sudut bahasa dan tafsiran ulama terdahulu dalam penghasilan karya penulisan. ${ }^{3}$

Berdasarkan lakaran sejarah, eksplorasi penulisan karya bercorak agama boleh dikatakan seiring dengan kedatangan Islam di Alam Melayu. Tradisi keilmuan dan pendidikan yang diwarisi dari zaman berzaman dapat menjejaki penulisan dan penghasilan manuskrip ataupun kitab-kitab kuning terdahulu. ${ }^{4}$ Penulisan karyakarya bercorak agama ini ditulis bermula dengan bertapaknya Islam dan penyebaran pengaruhnya di Alam Melayu. Seterusnya perkembangan penulisan ini membentuk satu kefahaman kepada masyarakat Melayu mengenai ajaran Islam secara berperingkatperingkat. Ia sesuai dengan sifat universal yang terdapat pada ajaran Islam. Ajaran Islam yang efektif telah membawa pengaruh dalam pembentukan bahasa dan kesusasteraan Melayu terutamanya dalam usaha menyebarkan fahaman Islam melalui bahasa persuratan dan penulisan. ${ }^{5}$ Ajaran Islam yang disebarkan ke Alam Melayu telah membawa budaya dan ilmu. Antara budaya yang dibawa oleh

2 Shafie Abu Bakar, "Keilmuan Islam dan Tradisi Pengajian Pondok" dalam Budi Kencana (Kuala Lumpur, 1994), 93-94.

3 Mahayudin Yahya, Naskhah Jawi Sejarah dan Teks Jilid 1 (Kuala Lumpur: Dewan Bahasa dan Pustaka, 1994), xvi.

4 Jamaludin, Saadan Man, Mohd Anuar Ramli, Mohammad Aizat, "Sumbangan Ulama Melayu Klasik dalam Menjana Budaya Ilmu di Alam Melayu" dalam Membongkar Rahsia Pendidikan Islam, ed. Norarfan Zainal et al. (Brunei: Penerbit Kolej Universiti Perguruan Ugama Seri Begawan, 2012), 285-289.

5 Salsabil Mohd Zain, Mustafa Abdullah, Muhammad Ali Hanafiah Norasid, "Penulisan Manuskrip Jawi di Alam Melayu: Satu Tinjauan Historis" dalam Islam dan Ketamadunan Melayu Sumbangan ke Arah Kemajuan Sejagat, vol. 1, ed. Mohd Roslan Mohd Nor \& Khadher Ahmad (Kuala Lumpur: Bahagian Penyelidikan dan Pembangunan, Akademi Pengajian Islam, Universiti Malaya, 2014), 236; Abdul Samad Ahmad, Sejarah Kesusasteraan Melayu (Kuala Lumpur: Dewan Bahasa dan Pustaka, 1965), 5-6. 
Islam adalah membaca dan menulis. ${ }^{6}$ Kedatangan ajaran Islam juga membawa bersama karya Islam yang akhirnya diminati oleh masyarakat ${ }^{7}$ dan membentuk satu perubahan dinamik terhadap budaya masyarakat Melayu. ${ }^{8}$ Impaknya, berlaku penyebaran Islam secara meluas dan ia memperlihatkan perkembangan yang pesat dalam tradisi penulisan di Alam Melayu. Kenyataan ini dikuatkan dengan tradisi tamadun Islam telah membuktikan melalui ajaran Islam yang dipupuk oleh baginda Rasulullah SAW adalah melalui kemahiran menulis. ${ }^{9}$

\section{SKOP DAN METODOLOGI}

Dalam menyempurnakan penulisan ini, metodologi kajian yang

$6 \quad$ Mahayudin Yahaya, Islam di Alam Melayu (Kuala Lumpur: Dewan Bahasa dan Pustaka, 1998), 60.

7 Rahmah Ahmad Osman dan Mohd Shahrizal Nasir, "Sastera Islam: Satu Perbandingan antara Pandangan Mohd Affandi Hassan dengan Abu al-Hasan Ali al-Nadwi," Jurnal e-Utama, vol. 3 (2011), 1.

8 Ahmad Misbah Muhamad Hilmi et.al., "Manuskrip Hujjatul Balighah Karya Syeikh Jalaluddin Alasy: Kajian Tahqiq Teks: Bab Pendakwaan," e-Jurnal Penyelidikan dan Inovasi, vol. III, no. I (2016), 140.

9 Ini jelas dapat dilihat bagaimana tindakan Rasulullah SAW dalam peperangan Badar. Baginda meminta setiap tawanan perang tentera musuh yang pandai menulis dan membaca agar mengajar sepuluh orang anak orang Islam kemahiran tersebut sebagai salah satu cara untuk mendapatkan pembebasan. Lihat Mubarakfuri S.R, al-Rahiq al-Makhtum: Bahth fi al-Sirah al-Nabawiyyah (Tanta: Dar al-Basyir, 1987). Demikian juga, para sahabat Nabi SAW juga menggalakkan anak-anak dan murid-murid mereka mencatat dan menulis. Antaranya Anas ibn Malik RA yang menggalakkan anaknya supaya menulis hadis. Begitu juga dengan 'Abd Allah ibn 'Abbas RA, 'Umar ibn alKhattab, 'Ali ibn Abi Talib yang menggalakkan murid-murid mereka supaya menulis dan merekodkan setiap ilmu yang dipelajari mereka. Lihat 'Ajjaj al-Khatib, Usul al-Hadith Ulumuhu wa Mustalahuhu (Jeddah: Dar al-Manarat, 1997), 171. 
digunakan oleh penulis ialah menggunakan reka bentuk kualitatif ${ }^{10}$ melalui pendekatan dua metode iaitu metode pengumpulan data dan metode analisis data. Secara keseluruhannya, kajian ini merupakan analisis dokumen berdasarkan kajian perpustakaan. Bagi mendapatkan bahan, maklumat dan data, pengkaji mengunakan kaedah merangkumi metode dokumentasi. Penulis mengumpulkan data dan maklumat yang dikaji melalui pelbagai sumber primer dan sekunder seperti karya asal fiqh, manuskrip, buku asal, jurnal, kajian ilmiah, kertas kerja seminar, akhbar, majalah dan bahan rujukan elektronik. Data-data yang dikutip dan dianalisis secara deskriptif dengan menggabungkan beberapa idea, pandangan dengan dapatan kajian yang lepas bagi menghasilkan suatu gambaran yang menyeluruh berkaitan perkembangan penulisan karya fiqh Melayu klasik. Setelah memperolehi datadata yang mencukupi dengan metode pengumpulan data, pengkaji akan menganalisis secara holistik maklumat tersebut dengan metode perbandingan, pengamatan dan pemerhatian karya-karya fiqh Melayu klasik.

\section{KEGIATAN AWAL PENULISAN AGAMA JAWI DI ALAM MELAYU}

Mengikut catatan sejarah, masyarakat Melayu telah lama mengenali tulisan, iaitu sebelum kedatangan Islam lagi di Alam Melayu. Hal ini berdasarkan penemuan batu bersurat zaman Srivijaya seperti Batu Bersurat Kedukan Bukit (683 M), Kota Kapur (686 M) dan Talang Tuwo $(684 \mathrm{M})$ yang ditulis pada abad ke-7M. Dalam bahasa Melayu kuno ia jelas menunjukkan bahawa masyarakat Melayu mempunyai tradisi tulisan dan penulisan sejak dahulu lagi. Walaupun tradisi tulisan telah lama wujud pada zaman pra-Islam

10 Penyelidikan kualitatif adalah penemuan-penemuan yang tidak dapat dicapai dengan menggunakan prosedur-prosedur statistik atau dengan cara kuantifikasi yang lain. Penyelidikan kualitatif dapat digunakan untuk meneliti kehidupan masyarakat, sejarah, tingkah laku, fungsionalisasi organisasi, pergerakan-pergerakan sosial atau hubungan kekerabatan. Lihat dalam Lexy J. Moleong, Metodologi Penelitian Kualitatif (Karya Cv: Bandung, 1993), 1-3; Basrowi Sukidin, Metode Penelitian Kualitatif Persepktif Mikro (Surabaya: Insan Cendakia, 2002), 1. 
seperti yang terdapat pada batu bersurat namun perkembangannya dalam kalangan rakyat amat terhad. ${ }^{11}$ Pada peringkat permulaan, perkembangan penulisan ini menjadi aktiviti bagi mereka yang berkepentingan sahaja khususnya kepada para rahib Hindu dan jurutulis istana. ${ }^{12}$ Ini kerana kesukaran untuk mendapatkan bahanbahan tulisan. Sekitar abad ke-15 selepas kedatangan Islam aktiviti penulisan ini di pelopori oleh golongan ulama dan golongan di istana yang melibatkan aktiviti mengarang surat perutusan, menyalin kitab, menyalin hikayat dan menyusun undang-undang dan peraturan disesuatu tempat. ${ }^{13}$ Boleh dikatakan penulisan awal di Alam Melayu ini membentuk paradigma dan intelektual dalam masyarakat Melayu. Hasilnya, pemikiran intelektual ini akhirnya membentuk gagasan intelektual melahirkan ulama dan sarjana Melayu yang memainkan peranan dalam kegiatan penulisan dan penghasilkan karya-karya pengajaran bagi rujukan masyarakat Melayu. Justeru, penulisan dan penghasilan karya dalam pelbagai corak dan pola penulisan menggambarkan dinamisme kearifan tempatan di rantau Alam Melayu dalam membina perkembangan peradaban dan budaya ilmu.

Masyarakat Melayu yang berkebolehan mula membaca dan menulis, mencatat ajaran-ajaran guru dalam kitab-kitab dengan tulisan tangan. Perkembangan pengajian Islam pada mulanya tertumpu kepada perkara-perkara asas dalam agama, ilmu fardu ain kemudiannya berkembang kepada pengajaran kitab-kitab bahasa Arab dan terjemahan dalam bahasa Melayu. Pengajian dan pengajaran ilmu bukan sahaja dijalankan di istana, malah surau, madrasah, masjid, pondok dan rumah-rumah persendirian juga turut digunakan untuk pengajian kitab-kitab agama dan al-Quran. Semasa pemerintahan kerajaan kesultanan Melayu Melaka, istana

${ }_{11}$ Makmur Harun, Firman \& Muhammad Yafri Yahya, Abms3203 Jawi dan Kajian Manuskrip Melayu, Buku Panduan Kursus Open University Malaysia (OUM), edisi. 1, 2016, 4-30; Ding Choo Ming, Kajian Manuskrip Melayu: Masalah, Kritikan dan Cadangan (Kuala Lumpur: Utusan Publications \& Distributors Sdn. Bhd, 2003), 10.

12 Muhammad Bukhari Lubis et.al., Tulisan Jawi Sehimpun Kajian (Shah Alam: Pusat Penerbitan Universiti (UPENA), 2006), 3.

13 Hamdan Hassan, "Tradisi Penulisan Sastera Melayu Tradisional," Jurnal Filologi Melayu (1997), 16-22. 
menjadi pusat pengajian untuk keluarga raja dan para pembesar, terdapat banyak buku dan sumber dari mazhab Syafi'e digunakan oleh para ulama sebagai bahan pengajaran mereka. mazhab Syafi'e menjadi pegangan yang dominan khususnya di rantau Alam Melayu. Hampir kesemua kitab kuning fiqh yang beredar dilingkungan pondok dan pesantren berpegang kepada pandangan mazhab Syafi'e dengan merujuk jalur Imam al-Nawāwi (631-676 H) daripada susur-galur Imam al-Rāfi'e (w. $623 \mathrm{H}) .{ }^{14}$ Menurut Oman Fathurrahman karya-karya tulisan tangan ${ }^{15}$ (manuskrip) tidak dapat dipisahkan dari tradisi besar Islam sejak abad ke-7 dan tersebar ke Alam Melayu sehingga dalam perkembangannya turut melahirkan tradisi besar penulisan yang berbentuk penulisan bercorak keagamaan. ${ }^{16}$ Pada peringkat awal perkembangan kegiatan penulisan terbahagi kepada pelbagai disiplin ilmu. Penggunaan penulisan di dalam bahasa Arab juga digunakan secara meluas ketika itu. ${ }^{17}$ Manakala hasil karya ditulis di dalam tulisan Jawi dan lebih dikenali sebagai kitab kuning. Ini merupakan kelangsungan tradisi ulama Alam Melayu yang terkenal dengan penulisan dan penghasilan karya agama. Karya-karya penulisan ini seterusnya menjadi teks rujukan dan pengajaran dalam sistem pengajian pondok, surau dan masjid serta institusi agama.

14 Mohd Anuar Ramli et al., "Kearifan Tempatan dalam Hukum Islam di Alam Melayu," Seminar Hukum Islam Semasa, Jabatan Fiqh dan Usul, Akademi Pengajian Islam Universiti Malaya Kuala Lumpur, 2018.

15 Manuskrip Melayu ialah karya yang bertulis tangan terutama dalam tulisan Jawi yang dihasilkan dalam lingkungan awal kurun ke16 sehingga awal kurun ke-20. Ia ditulis dalam bahasa rumpun Melayu mengenai alam dan tamadun Melayu. Ilmu dalam manuskrip Melayu juga merangkumi pelbagai bidang seperti kesusasteraan, sejarah, kitab agama, perubatan, undang-undang, ketatanegaraan, azimat dan petua; Portal Rasmi Perpustakaan Negara, http://www. pnm.gov.my/index.php/pages/view/88, tarikh capaian 5 Disember 2016.

16 Oman Fathurrahman, Filologi dan Islam Indonesia (Jakarta: Puslitbang Lektor Keagamaan, Kementerian Agama RI, 2010), 101.

17 Idris Awang \& Tengku Sarina Aini Tengku Kasim, "Pembudayaan Mazhab Syafi'e dalam Masyarakat Islam di Malaysia," Jurnal Fiqh no. 4 (2007), 157-172. 


\section{PENULISAN KARYA FIQH ALAM MELAYU}

Kedatangan Islam ke Alam Melayu adalah penyumbang utama kepada kelahiran kegiatan penulisan buku dan karya. ${ }^{18}$ Penulisan dan pengkaryaan merupakan suatu tradisi ulama Islam selain daripada belajar dan mengajar. Dalam catatan sejarah, perkembangan ilmu Islam dan penulisan karya fiqh Jawi Melayu di Alam Melayu telah berlaku pada sebelum atau pada abad ke16. Menurut Abdul Kadir Muhammad penulisan fiqh terbahagi kepada beberapa bahagian. Antaranya dapat dijelaskan penulisan awal hukum Islam, penulisan hukum Islam pada abad ke-19 dan penulisan hukum Islam abad ke-20. ${ }^{19}$ Kebanyakan karya bertulis yang dihasilkan oleh sarjana Melayu-Islam dalam pelbagai disiplin ilmu bersifat teori (seperti disiplin teologi) ataupun praktikal (fiqh dan tasawuf). ${ }^{20}$ Tidak dapat dinafikan usaha penulisan ini mempunyai pengaruh dalam tradisi keilmuan Alam Melayu. ${ }^{21}$ Dalam aspek penulisan fiqh terdapat pelbagai karya sama ada dalam bahasa Melayu atau Arab yang meliputi pelbagai metode penulisan sama ada penulisan hukum, terjemahan kitab bahasa Arab, soal jawab agama, ringkasan atau ulasan kepada sesuatu

18 Faizuri Abdul Latif \& Faisal @ Ahmad Faisal Abdul Hamid, “Tradisi Penulisan Hadith dalam Karya Ulama Melayu: Kajian Terhadap Kitab 'Aqidah al-Najin,” Jurnal Usuluddin, vol. 30 (2009), 92.

19 Abdul Kadir Haji Muhammad, Sejarah Penulisan Hukum di Malaysia (Kuala Lumpur: Dewan Bahasa dan Pustaka, 1996), 1-98.

20 Muhammad Abu Bakar, "Pendirian dan Pembangunan: Islamisasi dan Isu-Isu Semasa dengan Rujukan kepada Tugas Generasi Ulul Albab dalam Abad Ke-21" dalam Islam dan Masyarakat Maju (Kuala Lumpur: Dewan Bahasa dan Pustaka, 1993), 39-48.

21 Abdul Hadi W.M, "Islam di Indonesia dan Transformasi Budaya" dalam Menjadi Indonesia: 13 Abad Eksistensi Islam di Bumi Alam Melayu ed. Komaruddin Hidayat dan Ahmad Gaus AF (Jakarta: Mizan, 2006), 470-471. 
karya lain. ${ }^{22}$ Antara karya fiqh terawal Alam Melayu adalah karya Șirāt al-Mustaqīm. Ia menjelaskan hukum ibadat khusus seperti solat, zakat, puasa dan haji. ${ }^{23}$

Menurut Ahmad Juhari terdapat kira-kira 16000 manuskrip Melayu dalam tulisan jawi disimpan di perpustakaan dan muzium seluruh dunia, seperti London, Leiden, Singapura, Jakarta, Lisbon dan Berlin. ${ }^{24}$ Sementara itu, menurut Kajian Martin van Bruinessen dalam kajian karya-karya Melayu klasik Islam di Alam Melayu dalam pengumpulannya terhadap 900 judul kitab Melayu klasik. Terdapat 20\% bidang fiqh, $17 \%$ bidang akidah dan usuluddin, 12\% nahu arab, 8\% koleksi hadis, 7\% Tasawwuf dan tarikat, $6 \%$ akhlak, 5\% koleksi doa, wirid dan mujarrobat, dan 6\% kisah nabi, maulud dan manaqib. Dalam lakaran sejarah penulisan karya manuskrip berkembang pada $1400-1600 \mathrm{M}^{25}$ pada era keagungan intelektual Melayu dan zaman pertumbuhan ilmu

22 Najahudin Lateh et al., "Tematik Emas dalam Karya Fiqh Ulama Alam Melayu: Tinjauan Terhadap Kitab al-Sirat al-Mustaqim, Furu' al-Masail dan Bahr al-Madhi" Seminar Serantau Kajian Manuskrip Melayu dan Kearifan Tempatan 2013), 65; Tradisi perkembangan penulisan fiqh Melayu memfokuskan kepada tiga perkara utama. Pertama penulisan secara kronologi penceritaan perkembangan karya-karya fiqh Melayu yang tersebar di Alam Melayu. Penulisan ini dapat memberi gambaran berlakunya hasilan proses perkembangan karya fiqh Alam Melayu dari zaman ke zaman mengikut teori yang dibentangkan. Kedua penulisan dan analisa kandungan karya-karya dan hasilnya dimanfaatkan seperti penulisan metodologi, pemikiran dan aliran mazhab khusus, pendalilan, istinbath dan sebagainya. Ketiga penulisan biografi tokoh tertentu dengan pemikiran atau sumbangan tokoh terhadap perkembangan ilmu fiqh.

23 Abdul Rahman $\mathrm{Hj}$ Abdullah, Pemikiran Umat Islam di Alam Melayu: Sejarah dan Perkembangannya Hingga Abad Ke-19 (Kuala Lumpur: Dewan Bahasa dan Pustaka, 1990), 127.

24 Ahmad Juhari, "The Origin and Spread of The Jawi Script kertas kerja Sub-Regional Symposium on the Incorporation of the Languages of Asian Muslim Peoples into the Standardized Quranic Script," Kuala Lumpur, 2008.

25 Wan Mohd. Shaghir, Katalog Karya Melayu Klasik (Edisi Penyempurnaan) (Selangor: Khazanah Fathaniyyah, 2018), xxvixxvii. 
Islam. Ini kerana, wujudnya faktor kerajaan-kerajaan Islam $^{26}$ yang mendokong fuqaha Melayu selesa dan mampu menulis karya fiqh untuk menjawab permasalahan masyarakat. Dalam konteks penulisan karya fiqh Melayu ia dapat dibahagikan kepada dua kategori. Pertama, karya penulisan yang mengandungi perbincangan hukum dalam suatu aliran pemikiran mazhab seperti karya fiqh mazhab Syafi'e. Tradisi penulisan kebiasaannya terikat dalam bentuk matan, syarah (huraian), ta'liq (komentar), hasyiyah (anotasi), mukhtasar (ringkasan) dan tahqiq (edit). Kedua, karya penulisan yang lebih khusus dalam bidang 'ibadah, mu'amalah, mawarith dan siyasah. ${ }^{27}$ Apabila berlaku proses perkembangan penulisan secara konsisten maka timbul fasa penambahbaikan

26 Pada zaman kesultanan Aceh abad ke-17 pemerintah menggalakkan ulama menetap di Aceh untuk menyampaikan ilmu kepada rakyat. Selain itu, pusat pengajian juga didirikan di masjid untuk rakyat yang ingin mempelajari ilmu pengetahuan. Pelajar-pelajar disediakan peluang untuk melanjutkan pelajaran ke India, Mekah dan Mesir. Oleh itu, kesan besar peranan Sultan di Aceh lahirlah penulisan dalam pelbagai displin ilmu seperti ilmu fiqh, tasawwuf, ilmu kalam dan ilmu yang lain. Di samping itu, istana juga menjadi tempat tumpuan masyarakat Melayu. Boleh dikatakan tradisi perkembangan penulisan bermula dari istana. Raja-raja Melayu Alam Melayu seperti di Melaka, Johor, Pahang, Perlak, Pasai dan Aceh menjadikan ulama, jurutulis, penyair sebagai penulis, peyunting dan penterjemah karya-karya penulisan yang berkaitan dengan agama atau sejarah pemerintahan. Kebanyakan karya-karya ini ditulis menggunakan tulisan Jawi. Sokongan dari pihak istana menjadikan tradisi penulisan karya berkembang dengan baik; Harun Mat Piah et.al., Kesusasteraan Melayu Tradisional (Kuala Lumpur: Dewan Bahasa dan Pustaka, 2000), 37-38; Mohd Sidin Ahmad Ishak, Penerbitan dan Percetakkan Buku Melayu 1807-1960 (Kuala Lumpur: Dewan Bahasa dan Pustaka, 1998), 4.

27 Mohd Anuar Ramli et.al., "Sumbangan Ulama Melayu Klasik dalam Pembinaan Kearifan Tempatan di Alam Melayu," Jurnal Pengajian Melayu, 27 (1) (2016), 178-196. 
seterusnya terhasilnya pertumbuhan baru dalam penulisan karya fiqh Melayu. ${ }^{28}$

Penulisan karya tulisan Jawi khususnya dalam bidang fiqh boleh dikatakan berkembang seiring dengan perkembangan ilmu-ilmu lain. Ini kerana, ilmu fiqh berkembang sejajar dengan ilmu-ilmu Islam lain di Alam Melayu. Perkembangan awal bermula dengan tradisi lisan diikuti dengan hasil karya tulisan dan kemudian dalam bentuk cetakan. Kebanyakan penulisan dekad terawal penulisan karya fiqh mencerminkan realiti masyarakat iaitu perkara berkaitan ibadat berbanding yang mempunyai kandungan yang tersirat di sebalik kata-kata yang rencam seperti karya usul, fatwa dan khiläfìyah. Tidak dinafikan pengajian fiqh secara tidak langsung telah mula diperkenalkan semenjak Islam bertapak di Alam Melayu. Ini kerana, pendakwah dan mubaligh Islam awal lebih fokus menerapakan ajaran bersifat ibadat. Ianya ilmu yang utama perlu dipelajari oleh masyarakat Melayu yang baru mengenal Islam. Ini termasuklah ilmu fardu ain seperti bersuci, solat, berwuduk sebagai asas pemahaman ajaran agama. ${ }^{29}$ Pada peringkat awal dakwah Islam di Alam Melayu tidak terdapat sesi pengajian fiqh secara formal berdasarkan penggunaan metode dan pengajaran secara sistematik dengan menggunakan kitabkitab fiqh. Tradisi pengajian bercorak agama pada peringkat

28 Melalui penulisan fiqh secara tidak langsung kita dapat memahami sejarah perkembangan dan penulisan fiqh yang dicatatkan. Ini termasuklah metode penulisan, struktur, ciri dan gaya penulisan, fizikal karya, pemikiran dan budaya masyarakat lalu. Oleh itu, terdapat dua gambaran awal penulisan karya fiqh Melayu. Karya berbentuk terjemahan dari karya asal Bahasa Arab, kemudian disaring sehingga terhasilnya karya penulisan.

29 Rahimin Affandi Abdul Rahim, "al-Quran dan Peranan Ulama Melayu dalam Pemodenan Rantau Alam Melayu" dalam Warisan alQuran Peradaban Manusia ed. Mohd Radzi Othman et al. (Pulau Pinang: Universiti Sains Malaysia, 2005), 20-28. 
awal hanya dijalankan di istana-istana. ${ }^{30}$ Namun begitu, ini tidak bermakna ilmu fiqh diabaikan dan tidak diberi keutamaan ketika itu. Sebaliknya, karya fiqh telah wujud seawal abad ke-17 di Aceh yang merupakan pusat penyebaran dakwah Islam yang terkemuka selepas kejatuhan Melaka. Terdapat kemungkinan ilmu yang dipelajari pada ketika itu hanya dicatat dan ditulis sahaja sebagai bahan hafalan agama dan tidak dibukukan secara rasmi untuk tatapan umum.

Sebelum abad ke-17 tidak dapat dipastikan dengan jelas mengenai perkembangan ilmu fiqh di Alam Melayu. Walaupun begitu, masyarakat Islam mengakui akan kepentingannya. ilmu fiqh kebiasaanya mempunyai kesinambungan dengan displin ilmu lain yang mencakupi ilmu al-Quran, Syariah dan hadis. Ini dapat difahami, ilmu fiqh adalah ilmu yang berkaitan ibadat yang menjadi amalan seharian masyarakat Melayu. Ianya juga ilmu yang menjadi panduan kepada pembinaan etika dan moral masyarakat. ${ }^{31}$ Pada abad itu, pengajaran ilmu fiqh hanya dipelajari secara tidak formal melalui hafalan serta lisan dalam keadaan tulisannya yang tidak lengkap dan tidak dibukukan dalam bentuk karya penulisan. ${ }^{32}$ Antara karya-karya awal penulisan fiqh yang masyhur dan terpilih abad ke-17 berdasarkan pengaruh yang boleh penulis nyatakan adalah karya Șirāt al-Mustaqīm ${ }^{33}$ 1644M dan karya Mir'ah alȚullāb fì Tashīl al-Ma'rifat al-Ahkām wa al-Syarì'ah lì al-Mulk

30 Terdapat pengajian al-Quran pada awal kesultanan Melayu Melaka di mana seorang seorang alim bernama Maulana Sadar Jahan telah menjadi guru kepada Sultan Mahmud dan puteranya; William Girdlestone Shellabear, Sejarah Melayu (Kuala Lumpur, Fajar Bakti, 1975), 240.

31 Muhammad Mustaqim Mohd Zarif, "Penulisan Karya Hadis Alam Melayu Abad Ke-19: Antara Syeikh Nawawi Banten dan Syeikh Wan Ali Kutan al-Kalantani," dalam Sunnah Nabi Realiti dan Cabaran, ed. Fauzi Deraman, Ishak Sulaiman \& Faisal Ahmad Shah (Kuala Lumpur: Jabatan al-Quran dan Hadith, 2011), 353-370.

32 Ajidar Matsyah, "Jaringan Ulama-Ulama Melayu dalam Manuskrip," Seminar Serantau Kajian Manuskrip Melayu dan Kearifan Tempatan, 2013, Banda Aceh, Indonesia,

33 Sirat al-Mustaqim, MSS 144, Pusat Manuskrip Negara, Perpustakaan Negara Malaysia, Kuala Lumpur. 
al-Wahhāb ${ }^{34}$ 1672M. Karya Șirāt al-Mustaqìm adalah karya fiqh Melayu terawal ditulis di dalam Bahasa Melayu Jawi. Ia ditulis oleh Syeikh Nuruddin al-Raniri seorang ulama yang berasal dari India dan menetap di Acheh.

Manakala karya Mir'ah al-Thullāb ditulis oleh Syeikh Abd alRauf al-Fansuri. Karya Mir'ah al-Thullab merupakan karya fiqh berbentuk soal jawab khas untuk para Qādi. Kandungan karya penulisan dalam bentuk soal jawab ${ }^{35}$ namun ia dianggap pelengkap kepada karya Șirāt al-Mustaqim yang hanya menjelaskan persoalan rubu' ibadat. Jarak penulisan antara karya Șirāt alMustaqim 1644M dan karya penulisan Mir'ah al-Thullab 1672M adalah 28 tahun. Kedua-dua penulisan karya fiqh abad ke-17 ini bukanlah karya fiqh Melayu yang lengkap merangkumi kitab, bab dan fasl. Ia merangkumi kitāa dan $b \bar{a} b$ yang tertentu sahaja. Dalam konteks ini curahan ilmu yang diberikan oleh ulama terdahulu tidak diberikan secara sekaligus.

Oleh itu, struktur dan proses permulaan penulisan karya fiqh Melayu dibahagikan kepada kandungan kitāb, bāa dan faṣl. Kandungannya disusun mengikut tajuk dan huraian secara sistematik bagi memudahkan proses pembelajaran masyarakat Melayu diambil kira. Memang tidak dinafikan terdapat kekurangan kandungan perbincangan dan kupasan dalam penulisan karya fiqh Melayu. Ini boleh dilihat seperti kandungan huraian yang ringkas, penulisan bentuk saduran, terjemahan dan salinan. Namun, apabila terdapat kekurangan perbincangan dan huraian dalam topik ibadat tertentu maka ia akan ditambah baik oleh fuqaha Melayu selepasnya. Ini membuktikan apabila perkembangan karya itu berkembang mengikut peredaran masa dan zaman ia saling lengkap melengkapi dan wujud pertumbuhan baru dalam karya penulisan fiqh Melayu.

Sementara itu, karya penulisan fiqh Melayu abad ke-19 menunjukan perkembangan penulisannya yang dinamik dan

34 Mir'ah al-Thullab fi Tashil al-Ma'rifat al-Ahkam wal Syari'ah li alMulk al-Wahhab al-kifayah, MSS 1532, Pusat Manuskrip Negara, Perpustakaan Negara Malaysia, Kuala Lumpur

35 Jelani Harun, "Mir'at al-Tullab By Syeikh Abdul Rauf Singkel: A Preliminary Study of Manuscripts Kept in The Special Collections," Malay Literature, vol. 26, no. 2 (2013), 122-127. 
produktif. Kebanyakan karya fiqh yang masyhur ditulis pada abad ini lahirnya di Patani. Antara karya-karya masyhur dan terpilih pada abad ini adalah karya yang ditulis oleh Syeikh Daud al-Fatani. Antaranya karya $\bar{I} d a h$ al-Albāb ${ }^{36} 1809 \mathrm{M}$ yang membincangkan tentang fiqh munakahat menurut mazhab Syafi'e. ${ }^{37}$ Karya Ghāyah al-Taqrib $^{38} 1811 \mathrm{M}$ yang menjelaskan tentang pembahagian

36 Idah al-Albab, MSS 2602, Pusat Manuskrip Negara, Perpustakaan Negara Malaysia, Kuala Lumpur.

37 Tumpuan utama perbincangan karya hanya kepada isu nikah kahwin bagi memenuhi keperluan masyarakat di Alam Melayu yang baru menerima. Masyarakat Melayu ketika itu memerlukan satu panduan tatacara untuk memahami asas-asas munakahat Islam. Justeru, bagi menjelaskan objektif utama suatu perkahwinan fuqaha Melayu telah berusaha mengumpulkan informasi yang berkaitan dengan maksud perkahwinan yang telah ditetapkan Islam kepada suami dan isteri. Karya rintis fiqh munakahat ini ditulis dengan lengkap daripada karya-karya fiqh munakahat yang ada sebelumnya seperti fuqaha klasik Arab terdahulu. Contoh-contoh kitab yang terkenal dan kerap dijadikan sebagai rujukan adalah seperti Nayl al-Awtar karangan al-Shawkani, al-Mughni oleh Ibn Qudamah, al-Mughni al-Muhtaj oleh al-Syeikh Muhammad al-Sharbini al-Khatib, Badai ' al-Sanai “ fi Tartib al-Sharai' oleh al-Imam 'Ala' al-Din Abi Bakr bin Mas'ud al-Kasani al-Hanafi.

38 Ghayah al-Taqrib, MS 2384, Pusat Manuskrip Negara, Perpustakaan Negara Malaysia, Kuala Lumpur. 
harta pusaka mengikut ilmu faraid. ${ }^{39}$ Karya Nahj al-Rāghībin ${ }^{40}$ $1811 \mathrm{M}$ yang menjelaskan tentang fiqh muamalat. ${ }^{41}$ Karya Bulūgh al-Marām ${ }^{42} 1812 \mathrm{M}$ yang menjelaskan tentang takbiratul ihram tentang niat mendirikan solat mengikut pandangan mazhab Syafi'e..$^{43}$ Karya Hidāyah al-Muta'allim wa 'Umdah al-Mu'allim ${ }^{44} 1828 \mathrm{M}$. Ia antara karya fiqh yang paling lengkap ditulis menjelaskan berhubung aqidah, fiqh dan tasawwuf, namun

39 Hasil pemerhatian, karya Ghayah al-Taqrib bercampur antara tulisan Jawi klasik dan tulisan Arab. Dalam membahaskan persoalan ilmu faraid Syeikh Daud al-Fatani mengambil pendekatan dengan mendatangkan konsep dan ta'rif ilmu faraid agar ia mudah difahami oleh masyarakat Melayu pada ketika itu. Ini dapat difahami ilmu faraid adalah ilmu yang kurang diberi perhatian oleh masyarakat masa kini apatah lagi bagi masyarakat Melayu terdahulu kerana kesukaran untuk memahami ilmu tersebut. Dalam perkembangan urutan penyenaraian karya fiqh Syeikh Daud Fatani telah meletakkan satu asas penyenaraian perbincangan karya fiqh yang sistematik mengikut tahun. Bermula urutan penyenaraian tajuk ibadat, diikuti muamalat, munakahat dan ilmu faraid. Ini menunjukan ketajaman dan pengamatan yang tinggi pemikiran Syeikh Daud Fatani dalam ilmu fiqh. Tidak hairanlah penulisan karya fiqh Syeikh Daud Fatani diakui kehebatannya oleh ulama di dalam dan di luar Alam Melayu.

40 Nahj al-Raghibin, MSS 332, Pusat Manuskrip Negara, Perpustakaan Negara Malaysia, Kuala Lumpur.

${ }^{41}$ Penulisan karya Nahj al-Raghibin menjelaskan dengan terperinci segala hukum jual beli yang dibahagikan kepada kitab hukum berkedai, syarikat, ikrar, hukum meminjam dan membahagikan keuntungan.

42 Bulugh al-Maram, MSS 733, Pusat Manuskrip Negara, Perpustakaan Negara Malaysia, Kuala Lumpur.

43 Kandungan karya membincangkan tentang niat ketika memulakan takbiratul Ihram. Ia berkaitan niat ketika memulakan solat yang sah menurut mazhab Syafi'e. Syeikh Daud menggunakan pendekatan dengan mendatangkan maksud niat secara hakiki dari sudut lughah dan syar'i. Menurut Syeikh Daud:...adapun hakikat niat itu pada lugah qasd al-syai artinya mensahajakan sesuatu dan pada syarak itu iaitu qasd syai muqtarinan yaf'luhu;Bulugh al-Maram, MSS 733, Pusat Manuskrip Negara, Perpustakaan Negara Malaysia, Kuala Lumpur.

44 Hidayah al-Muta'allim Wa 'Umdah al-Mu'allim, MS 4373, Pusat Manuskrip Negara, Perpustakaan Negara Malaysia, Kuala Lumpur. 
kandungan utamanya adalah perbincangan perkara fiqh. ${ }^{45}$ Karya Fath al Manan $1834 \mathrm{M}^{46}$ karya yang membahaskan mengenai aqidah, fiqh dan tasawwuf. Karya Jawāhir al-Saniyyah $1836 \mathrm{M}^{47}$ yang menjelaskan tentang aqidah ahli Sunnah wal Jama'ah, ilmu fiqh dan ilmu tasawwuf. ${ }^{48}$ Karya Sullam al-Mubtadī 1836M ${ }^{49}$ tentang ilmu fiqh, aqidah dan tasawwuf. ${ }^{50}$ Karya Furu' al-Masāil

45 Karya penulisan Hidayah al-Muta'allim antara karya fiqh Melayu Jawi yang paling lengkap perbincangannya. Terdapat juga perbincangan mengenai ilmu akidah dan tasawwuf namun perbincangan ilmu fiqh dilihat lebih dominan. Ia merangkumi judul kitab, rubu', bab dan fasl. Karya ini diklasifikasikan sebagai karya gabungan tiga ilmu yang membincangkan tentang syarat taklif dan hukum taklif, rukun iman, rukun Islam, syarat Islam dan cabang iman. Perbincangan ilmu fiqh bermula dari bab toharah hingga bab al-Jinayah.

46 Fath al-Manan, MSS 21, Pusat Manuskrip Negara, Perpustakaan Negara Malaysia, Kuala Lumpur.

47 Jawahir al-Saniyyah, MS 4373, Pusat Manuskrip Negara, Perpustakaan Negara Malaysia, Kuala Lumpur.

48 Kandungan penulisan karya terbahagi kepada beberapa bahagian. Di awal penulisan, dijelaskan tentang akidah ahl sunnah wa al-jamà 'ah berkaitan zat keesaan Allah SWT dan sifat-sifat Allah. Di bahagian kedua diterangkan perkara berkaitan fardu ain seperti sembahyang, puasa, haji dan zakat. Dibahagian ketiga mengenai hukum-hukum berkaitan isu hukum seperti nikah, talak, zina, pembahagian harta dan hak penjagaan anak. Walaupun perbincangan topik usuluddin dan fiqh mendominasi dalam kandungan karya penulisan namun aspek-aspek tasawwuf juga tidak ketinggalan dikupas oleh Syeikh Daud al-Fatani seperti perbincangan mengenai kelebihan kalimah tauhid dan tazkiyah al-Nafs (pembersihan jiwa) dan perjalanan alSuluk Tariqah kepada Rasulullah SAW.

49 Sullam al-Mubtadi, MS 27, Pusat Manuskrip Negara, Perpustakaan Negara Malaysia, Kuala Lumpur.

50 Kandungan karya ini ditulis dalam gabungan tiga ilmu iaitu fiqh, aqidah dan tasawwuf. Ini termasuk perbincangan mengenai perkaraperkara yang wajib dipelajari dalam fardu ain. Antara perkara yang disentuh iktikad, sembahyang, puasa, zakat, haji, korban, hukum faraid dan hukum nikah. 
wa Usul al-Wasāil 1841M $\mathrm{M}^{51}$ yang menjelaskan tentang furuk fiqh dalam mazhab Syafi'e. ${ }^{52}$

Abad ke-19 adalah abad yang sangat produktif dalam perkembangan karya fiqh Melayu. Penulisan dan penghasilan karya fiqh abad ke-19 telah membuktikan kemampuan ulama Patani untuk menulis karya figh yang bermutu, produktif dan konsisten. Hal keadaan ini berbeza dengan penulisan awal karya fiqh di Acheh dan Tanah Melayu. Walaupun terdapat penulisan fiqh dari Tanah Melayu seperti karya tulisan fiqh Tok Pulau Manis karya al-Kifāyah $1726 \mathrm{M}^{53}$ dan penulisan fiqh dari Acheh

51 Furu' al-Masail wa Usul al-Wasail, MS 553, Pusat Manuskrip Negara, Perpustakaan Negara Malaysia, Kuala Lumpur.

52 Syeikh Daud bin Abdullah al-Fatani memulakan penulisan karya dengan menulis tentang ilmu tauhid. Kandungan utama perbincangan karya adalah tentang furuk fiqh dalam mazhab Syafi'e. Selain itu, karya ini juga membincangkan hukum jenayah, jihad, kehakiman, pendakwaan dan kesaksian. Sumber rujukannya ialah penulisanpenulisan fuqaha mazhab Syafi'e yang muktabar iaitu Minhaj al-Talibin, Tuhfah al-Muhtaj bi Syarh al-Minhaj dan Nihayah alMuhtaj.

53 Ismail. C.D. Tokoh-tokoh Ulama Semenanjung Melayu (1) (Kelantan: Majlis Agama Islam dan Adat Istiadat Melayu Kelantan, 2012). 
seperti Șirat al-Mustaqìm dan Sabīl al-Muhtadīn ${ }^{54}$ namun tidak dapat menandingi produktiviti penulisan karya fiqh di Patani. Perkembangan karya fiqh Melayu di Patani berada dalam suasana perkembangan yang pesat dan dinamik. Bahkan, antara faktor yang mendorong ulama Patani mampu menulis secara konsisten kerana mereka dilahirkan dalam keluarga yang mementingkan ilmu pengetahuan dan keluarga yang terdiri daripada tokoh-tokoh agama yang dihormati dan disegani oleh masyarakat. Antaranya seperti Syeikh Daud al-Fatani yang diketahui berasal dari keluarga ulama. Menurut salasilah keturunannya, beliau berasal daripada

54 Pada dasarnya, pada abad ke-17 tidak hanya terdapat dua karya penulisan fiqh di Alam Melayu. Terdapat banyak karya-karya fiqh ditulis pada abad ke-17 dan 18. Ini kerana tradisi penyalinan naskhah telah lama direkodkan di Alam Melayu serta terdapat beberapa penulisan yang dicatatkan pada abad tersebut. Menurut Mursyid, antara penulisan awal di Aceh adalah karya al-Hadi al-Muhtaj $f i$ Syarh al-Minhaj ditulis oleh Imam Abi Qasim Imamuddin Abdul Karim Ar-Rafi'e 1610M. Penulisan karya ini memberikan kesan dan pengaruh kepada corak fiqh di Aceh. Sementara itu, menurut Dwi Laili Sukmawati terdapat beberapa naskhah fiqh berkaitan hukum Islam yang ditulis di Madura satu daerah di Jawa Timur yang menyimpan karya manuskrip sejak sekian lama. Sementara itu, Ali Rosdin menegaskan terdapat sekitar 340 buah naskhah terdapat dalam pernaskahan Buton, Pulau Sulawesi di kawasan timur Indonesia. Ini termasuklah naskhah-naskhah hukum yang membentuk penulisan fiqh. Ini dapat diketahui tradisi pernaskahan di Buton berlangsung seiring dengan perkembangan Islam. Perkembangan penulisannya memuncak ketika pemerintahan Sultan La Ode Muhammad Idrus Kaimuddin 1824-1851M. Ketika itu, kegiatan penulisan karya dan naskhah berlangsung dengan pesat dan kebanyakannya atas perintah Sultan Muhammad Idrus Kaimuddin yang dikenali sebagai Sultan dan ulama besar Buton. Tidak dinafikan lokasi perkembangan penulisan fiqh Melayu sangat pesat di Aceh dan kawasan sekitarnya. Mursyid, "Corak Fiqh di Aceh Pada Masa Kerajaan (Kajian Atas Naskah Al-Hadi al-Muhtaj fi Syarah al-Minhaj Karya Imam Abi Qasim Imamuddin Abdul Karim Ar-Rafi'i)," al-Qalam vol. 17 no. 1 (2011), 105; Ali Rosdin, "Buton dan Tradisi Pernaskahan," International Journal of the Malay World and Civilisation (Iman) 3 (1) (2015), 51-53. 
keturunan para alim-ulama. ${ }^{55}$ Bapa beliau adalah Wan Abdullah dan datuknya Wan Idris. Kedua-duanya adalah ulama besar Patani yang masyhur pada zamannya. ${ }^{56}$ Selain itu, terdapat banyak pusat pengajian dan pondok di Patani. Keberadaan pusat pengajian dan pondok-pondok ini membawa kepada keperluan penulisan karyakarya tulisan untuk dipelajari di pondok-pondok sekitar Patani. ${ }^{57}$ Ramai dikalangan pemuda dan remaja menyertai pondok di Patani untuk mempelajari ilmu termasuklah ilmu fiqh. Ketika Islam mula disebarkan masyarakat Islam Patani mula berminat kepada ilmu pengetahuan. Ini kerana dengan pemahaman ilmu fiqh mereka dapat melaksanakan ibadat dengan lebih sempurna.

Di samping itu, budaya setempat memainkan peranan intelektual dalam masyarakat. Ini kerana kewujudan pembudayaan ilmu yang berkembang dalam masyarakat secara tidak langsung mewujudkan perkembangan budaya menulis. Ini dapat dilihat daripada kesan menuntut ilmu dan pengaruh tempat memainkan peranan penting dalam menterjemahkan peranan ulama Patani yang mampu mengarang karya-karya agama Jawi khususnya karya fiqh. Suasana kemasyarakatan ${ }^{58}$ ini sedikit sebanyak mempengaruhi minda, paradigma keilmuan serta pemikiran intelektual ulama Patani dalam menghasilkan karya-karya fiqh yang bermutu tinggi serta membina suatu falsafah tindakan dalam masyarakat. Begitu juga, kebanyakan ilmuan di Patani mendapat pendidikan tinggi agama di Mekah dan menetap di sana dalam satu tempoh masa

55 Ismail Che Daud, Tokoh-tokoh Ulama Semenanjung Melayu (1) (Kelantan: Majlis Agama Islam dan Adat Istiadat Melayu Kelantan, 2012), 15-17.

56 Wan Mohd. Shaghir Abdullah, Syeikh Daud al-Fathani Pengarang Ulung Asia Tenggara (Kuala Lumpur: Khazanah Fathaniyyah, 2018), 10-13.

57 Kesan daripada proses Islamisasi di Patani dan keperluan kepada bahan-bahan pengajaran dan pembelajaran maka timbul permintaan dan keperluan kepada karya penulisan dan proses mencatatkan ilmu. Bagi memenuhi tuntutan keperluan ilmu dan pengajaran maka lahirlah keperluan kepada karya-karya penulisan sebagai teks pengajian di masjid, pondok dan pusat-pusat pengajian.

58 Wan Kamal Mujani, "Peranan dan Sumbangan Ulama Patani terhadap Perkembangan Pendidikan di Tanah Melayu," dalam Ulama Patani Ketokohan dan Keilmuan, ed. Farid Mat Zain et al. (Bangi: Universiti Kebangsaan Malaysia, 2016), 189. 
yang panjang. Mereka mendalami dan menekuni pengajian ilmu yang merangkumi ilmu tauhid, fiqh dan tasawwuf. Apabila pulang ke ke Patani mereka membawa amanah ilmu dengan mengajar dan menulis ilmu tersebut agar dapat disebarkan seterusnya memberi manfaat ilmu kepada masyarakat setempat. Ini menjadikan sarjana dan ulama yang berilmu dan faqih di dalam menguasai sesuatu ilmu. Apabila sesuatu ilmu di dalam bidang itu dapat dikuasai maka ia mudah untuk diterjemahkan dalam bentuk penulisan. Justeru, pada asasnya tidak semua penulisan karya-karya fiqh abad ke-19 merupakan karya fiqh yang lengkap secara keseluruhannya yang merangkumi kitab, bab, fasal dan tajuk namun ditulis dan dikarang dengan bahagian dan bab yang tertentu sahaja. Ini kerana, kandungan dan perbincangan ilmu yang diberikan oleh ulama terdahulu tidak diberikan secara sekaligus.

Mereka membahagikan bab dan fasal untuk memudahkan masyarakat yang ingin mempelajari dan memahami ajaran Islam pada peringkat awal penyebaran Islam. Apabila terdapat kekurangan perbincangan dan perbahasan di dalam karya ibadat maka penambahbaikan akan dilakukan oleh ulama selepasnya. Oleh itu, terdapat pertumbuhan baru pada karya fiqh Melayu pada suatu abad kepada abad yang lain mengenai perbincangan ilmu fiqh.

\section{Jadual 1: Subjek Penulisan Karya Fiqh Melayu Klasik Masyhur dan Terpilih}

\begin{tabular}{|c|l|l|c|c|}
\hline Bil. & $\begin{array}{c}\text { Karya Fiqh Melayu } \\
\text { Abad Ke-17 Hingga Ke- } \\
\text { 19 Masyhur \& Terpilih }\end{array}$ & \multicolumn{1}{|c|}{ Nama Pengarang } & Tahun & Abad \\
\hline 1. & Șirāt al-Mustaqīm & Syeikh Nurudin al-Raniri & $1644 \mathrm{M}$ & 17 \\
\hline 2. & Mir'ah al-Tullāb & $\begin{array}{l}\text { Syeikh Abdul Rauf al- } \\
\text { Fansuri }\end{array}$ & $1672 \mathrm{M}$ & 17 \\
\hline 3. & al-Kifāyah & $\begin{array}{l}\text { Syeikh Abdul Malik bin } \\
\text { Abdullah }\end{array}$ & $1726 \mathrm{M}$ & 18 \\
\hline 4. & Hidāyah al-Awām & Syeikh Jalaluddin al-Asyi & $1727 \mathrm{M}$ & 18 \\
\hline 5. & Safinah al-Hukkām & Syeikh Jalaluddin al-Asyi & $1740 \mathrm{M}$ & 18 \\
\hline 6. & Hujjah al-Bālighah & Syeikh Jalaluddin al-Asyi & $1745 \mathrm{M}$ & 18 \\
\hline 7. & Sabīl al-Muhtadīn & $\begin{array}{l}\text { Syeikh Muhammad } \\
\text { Arshad al-Banjari }\end{array}$ & $1780 \mathrm{M}$ & 18 \\
\hline
\end{tabular}




\begin{tabular}{|c|c|c|c|c|}
\hline 8. & $\bar{I} d a h$ al-Albāb & Syeikh Daud al-Fatani & $1809 \mathrm{M}$ & 19 \\
\hline 9. & Ghāyah al-Taqrib & Syeikh Daud al-Fatani & $1811 \mathrm{M}$ & 19 \\
\hline 10. & Nahj al-Rāghibīn & Syeikh Daud al-Fatani & $1811 \mathrm{M}$ & 19 \\
\hline 11. & Bulugh al-Marām & Syeikh Daud al-Fatani & $1812 \mathrm{M}$ & 19 \\
\hline 12. & Hidāyah al-Muta'allim & Syeikh Daud al-Fatani & $1828 \mathrm{M}$ & 19 \\
\hline 13. & Fath al-Manan & Syeikh Daud al-Fatani & $1834 \mathrm{M}$ & 19 \\
\hline 14. & Jawāhīr al-Sanīyyah & Syeikh Daud al-Fatani & $1836 \mathrm{M}$ & 19 \\
\hline 15. & Sullam al-Mubtadī & Syeikh Daud al-Fatani & $1836 \mathrm{M}$ & 19 \\
\hline 16. & $\begin{array}{l}\text { Furū'al-Masā'il wa } \\
\text { Ușūl al-Wasā'il }\end{array}$ & Syeikh Daud al-Fatani & $1841 \mathrm{M}$ & 19 \\
\hline 17. & Fath al-Mubin & $\begin{array}{l}\text { Syeikh Muhammad } \\
\text { Shalih bin Muhammad } \\
\text { Murid Rawa }\end{array}$ & $1856 \mathrm{M}$ & 19 \\
\hline 18. & Minhah al-Qarīb & $\begin{array}{l}\text { Syeikh Wan Abd al- } \\
\text { Samad al-Kalantani }\end{array}$ & $1882 \mathrm{M}$ & 19 \\
\hline 19. & Mațla'al-Badrayn & $\begin{array}{l}\text { Syeikh Muhammad bin } \\
\text { Ismail Daud al-Fatani }\end{array}$ & $1886 \mathrm{M}$ & 19 \\
\hline 20. & $\begin{array}{l}\text { Kashf al-Litham 'An As- } \\
\text { Ilah al-Ānām }\end{array}$ & $\begin{array}{l}\text { Syeikh Zainal Abidin bin } \\
\text { Muhammad al-Fatani }\end{array}$ & $1890 \mathrm{M}$ & 19 \\
\hline 21. & Bahjah al-Mubtadin & $\begin{array}{l}\text { Syeikh Ahmad bin } \\
\text { Muhammad Zain al- } \\
\text { Fatani }\end{array}$ & $1893 \mathrm{M}$ & 19 \\
\hline 22. & Al-Fatāwa al-Fațānīyyah & $\begin{array}{l}\text { Syeikh Ahmad bin } \\
\text { Muhammad Zain al- } \\
\text { Fatani }\end{array}$ & - & 19 \\
\hline 23. & $\begin{array}{l}\text { Wushah al-Afrāh wa } \\
\text { Ashbāh al-Falāh }\end{array}$ & $\begin{array}{l}\text { Syeikh Muhammad bin } \\
\text { Ismail Daud al-Fatani }\end{array}$ & $1894 \mathrm{M}$ & 19 \\
\hline 24. & $\begin{array}{l}\text { al-Thimār al-Ladhidhah } \\
\text { 'alā al-Riyāẹ al-Badi'ah }\end{array}$ & $\begin{array}{l}\text { Syeikh Ahmad bin } \\
\text { Muhammad Yunus } \\
\text { Lingga al-Jawi }\end{array}$ & $1894 \mathrm{M}$ & 19 \\
\hline 25. & $\begin{array}{l}\text { Nūr al-Sham 'ah fì Ahkōm } \\
\text { al-Jum'ah }\end{array}$ & $\begin{array}{l}\text { Syeikh Ahmad Khatib } \\
\text { bin Abd al-Latif } \\
\text { Minankabawi }\end{array}$ & $1896 \mathrm{M}$ & 19 \\
\hline
\end{tabular}




\section{PENULISAN KARYA FIQH ABAD KE-18}

Walaupun terdapat banyak ${ }^{59}$ karya penulisan fiqh Melayu di rantau Alam Melayu, ${ }^{60}$ namun penulis hanya memfokuskan penulisan ini kepada lima karya penulisan fiqh sahaja. Ia adalah antara penulisan fiqh yang masyhur dan terkenal di Alam Melayu berdasarkan kepada pengaruh penulisan pada zaman tersebut. Antara karya penulisan fiqh abad yang ke-18 yang masyhur dan terpilih ${ }^{61}$ di

59 Menurut Van Bruinessen beliau menyenaraikan sebanyak 900 judul kitab Melayu klasik yang dikumpulkannya. Ia merangkumi $20 \%$ bidang fiqh dan selebihnya adalah karya-karya Melayu Jawi yang merangkumi berbagai displin ilmu; lihat Van Bruinessen, M. (1990), "Kitab Kuning; Books in Arabic Script Used in the Pesantren Milieu; Comments on a New Collection in the KITLV Library," dalam Bijdragen tot de TaalLand-en Volkenkunde 146, no: 2/3. Leiden; Melalui carian penulis di Pusat Manuskrip Negara terdapat beberapa karya tentang penulisan ilmu fiqh. Antaranya MS 471 karya Kitab Sembahyang 1844M, MS 258 Bicara Fiqh Sembahyang, MS 285 Kitab Khutbah Hari Raya, MS 503 Kitab al-Nikah, MS 502 Kelebihan Isteri Berbuat baik terhadap Suani 1860M. Kesemua karya ini boleh dikategorikan sebagai risalah fiqh kerana kandungan dan perbincangannya ringkas dan tidak lengkap. Terdapat juga karya fiqh Melayu dikategorikan masyhur seperti karya Bughyah al-Tullab li Murid Ma'rifah al-Ahkam bi al-Thawab tulisan Syeikh Daud alfatani. Karya Ghayah al-Taqrib fi al-Irth Wa At-Ta sib 1811M. Karya Muniah al-Musalli 1827M tulisan Syeikh Daud al-Fatani. Karya Kifayah al-Ghulam fi Bayan Arkan al-Islam wa Syuruthihi tulisan Syeikh Ismail bin Abdullah al-Minangkabawi dan lain-lain lagi. Penulis tidak memasukkan kesemua karya penulisan kerana terdapat beberapa kekangan. Antaranya, penulis tidak menemui karya secara lengkap.

60 Nurdin AR, "Penggalian dan Inventarisasi 1000 Judul Naskah Melayu di Banda Aceh," Jurnal CMES, vol. x, no. 2, edisi Julai (2017), 170-179.

61 Penulis mengambil satu contoh pengaruh karya Sabìl al-Muhtadīn dalam perkembangan penulisan ilmu figh di Alam Melayu. Karya ini sering dijadikan rujukan oleh ulama dalam penulisan fiqh Melayu; Auni Hj. Abdullah, "Penulisan Ilmu Fiqh Di Alam Melayu," Majalah Dian Daiges, bil. 103, Nov 1977; Abd. Ghani Othman, Tatacara Penyembelihan Menurut Islam (Alor Setar: Jabatan Hal Ehwal Agama Islam Negeri Kedah, 2010), 60-85. 
Alam Melayu adalah karya al-kifāyah ${ }^{62} 1726 \mathrm{M}$ yang ditulis oleh Tok Pulau Manis. Karya penulisan fiqh ini dianggap sebagai penulisan fiqh terawal di Tanah Melayu. ${ }^{63}$ Karya ini dikarang oleh Tok Pulau Manis menggunakan dakwat hitam, rubrikasi perkataan tertentu dan ditulis atas kertas Belanda. Karya ini merangkumi beberapa gabungan displin ilmu usuluddin dan fiqh. Ia menjelaskan keperluan-keperluan yang harus diketahui oleh seorang Muslim mengenai akidah keimanan berdasarkan rukun iman yang enam dan keperluan muamalat berdasarkan rukun Islam yang lima. Dalam bidang ibadat, kandungannya menjelaskan tentang amalan seorang Muslim merangkumi bersuci, sembahyang, zakat, puasa, korban, perkara berkaitan dengan haji serta perkara yang halal dan haram dimakan. Walaupun Tok Pulau Manis dikenali melalui penulisan Kitab Hikam Melayu ${ }^{64}$ namun beliau berjaya menulis dua lagi karya fiqh iaitu Risālah al-Naql dan Risālah Kayfìyah

62 al-Kifayah, MS 517, Pusat Manuskrip Negara, Perpustakaan Negara Malaysia, Kuala Lumpur; Pusat Manuskrip Negara, Perpustakaan Negara Malaysia, Kuala Lumpur.

63 Zurita Mohd Yusoff et.al., Tok Pulau Manis: Pioneer of Fiqh Writings in the Malay Peninsular, Asian Social Science; vol. 11, no. 1 (2015); al-kifayah yang bernombor MSS 517 disalin oleh Muhammad Hussain bin Abdullah Latif bin Almarhum Abdul Mu'min pada 1880M di Kampung Beris, negeri Kelaba, Fatani. Haji Muhammad Hussain bin Abdullah Latif adalah seorang ulama besar dan lebih dikenali dengan nama Tok Kelaba. Beliau mula berminat menyalin manuskrip setelah diperintahkan oleh gurunya Syeikh Muhammad Zain bin Mustafa al-Fatani di Pondok Bendang Daya lagi. Jumlah karya manuskrip yang disalin oleh Tok Kelaba yang ditemui berbanding dengan penyalin yang lain adalah banyak. Oleh itu, Tok Kelaba sangat di kenali di Alam Melayu seorang tokoh penyalin manuskrip yang berkelibar dan terkenal. Penglibatan beliau di dalam penyalinan manuskrip ini mengambil satu tempoh yang sangat lama; Wan Mohd Shagir Abdullah, "Tokoh-tokoh Penyalin Manuskrip Kitab dari Semenanjung Tanah Melayu," Jurnal Filologi, jilid. 2 (1993), 48.

64 Kitab Hikam Melayu, MSS 22, Pusat Manuskrip Negara, Perpustakaan Negara Malaysia, Kuala Lumpur; karya tasawwuf ini membincangkan persoalan tasawwuf mengikut aliran tarikat Syaziliah tentang zat dan makrifat Allah SWT. 
Nīyyah. Antara ketiga-tiga ini, karya al-Kifāyah adalah karya yang paling menonjol kerana ia merangkumi perbincangan pelbagai topik ibadat dan dianggap sebagai karya penulisan fiqh terawal ditulis di Terengganu dan antara yang tertua di Alam Melayu selepas karya Șirāt al-Mustaqīm. Urutan perkembangan penulisan karya fiqh Melayu abad ke-18 dikembangkan dengan penulisan karya Hidāyah al-Awwām ${ }^{65} 1727 \mathrm{M}$ ditulis oleh Syeikh Faqih Jalaluddin al-Asyi. Melalui kajian awal penulis pada tahun 2016 dan 2017 di Pusat Manuskrip Negara tidak menemui karya Hidāyah al-Awwām. Karya manuskrip ini dapat penulis temui pada julai 2019 kerana terdapat tambahan karya baru di Pusat Manuskrip Negara. Karya yang penulis temui di Pusat Manuskrip Negara adalah karya yang sudah uzur. Berkemungkinan besar ia akan rosak dan tidak boleh lagi ditatap dan dikaji oleh generasi sekarang dan akan datang. Justeru akan berlaku kehilangan bukti kesarjanaan fuqaha Melayu silam dan tidak boleh dimanfaatkan oleh generasi akan datang. Karya tulisan ini bermaksud 'pada menyatakan perintah Agama Islam.' Ia merupakan karya penulisan fiqh yang ringkas dan umum. ${ }^{66}$ Perkembangan penulisan karya fiqh Melayu pada abad ke-18 digerakan dengan penulisan Safinah

65 Hidayah al-Awwam MSS 3843 (F.A) Pusat manuskrip Negara, Perpustakaan Negara Malaysia, Kuala Lumpur; http://www.nu.or. id/post/read/76330/fiqih-Alam Melayu-abad-ke-18-m-karya-faqihjalaluddin-Aceh.

66 Dalam catatan muqaddimah Syeikh Jalaluddin al-Asyi menjelaskan karya Hidayah al-Awwam ditulis pada $1727 \mathrm{M}$ dan dihuraikan dalam bentuk umum dan ringkas. Selain itu, bahasa dan kalimah penulisannya agak sukar difahami. Kebanyakan karya fiqh abad ke-18 mempunyai teks dan kandungan yang lebih khusus kepada penulisan karya terjemahan, saduran, menyalin dan menulis semula apa yang telah ditulis di dalam kitab-kitab klasik Arab. Tidak terdapat corak penulisan khusus seperti penulisan fatwa dan usul dalam karya abad awal penulisan fiqh; Hidayah al-Awwam MSS 3843 (F.A) Pusat manuskrip Negara, Perpustakaan Negara Malaysia, Kuala Lumpur, 2. 
al-Hukkām fì Talkhīs al-Khishām ${ }^{67}$ 1740M ditulis oleh Syeikh Jalaluddin al-Asyi. Ia ditulis atas perintah Sultan Alauddin Johan Syah dan bentuk penulisannya berupa tulisan tangan. Kandungan perbincangan adalah fiqh menurut mazhab Syafi'e. Dalam catatan pengantar penulisan dinyatakan kandungan karya menjelaskan istilah-istilah, peringatan untuk golongan hakim yang zalim dan beberapa kaedah. Seterusnya, perkembangan penulisan karya fiqh Melayu abad ke-18 dikembangkan dengan penulisan karya Hujjah al-Bālighah 'Alā Jamā'ah al-Mukhāsamah. ${ }^{68}$

Karya ini juga ditulis oleh Syeikh Jalaluddin al-Asyi pada abad ke- $18^{69}$ pada 1745 . Kandungan perbincangan karya terbahagi kepada tiga bab utama iaitu imam atau pemimpin yang melaksanakan hukuman ( $a l-Q \bar{a} d \bar{l})$, dakwaan dan bukti ( $d a$ 'wa wa bayyinah) serta saksi dan sumpah (shuhüd wa al-khalf). Manakala perkembangan karya fiqh Melayu seterusnya dapat dilihat dengan lahirnya karya penulisan Sabïl al-Muhtadìn li al-Tafaqquh fì Umur al-Dīn $n^{70} 1780 \mathrm{M}$ ditulis oleh Syeikh Muhammad Arshad al-Banjari. Karya Sabīl al-Muhtadīn merupakan karya yang masyhur dan terkenal tersebar luas diseluruh Alam Melayu. Ia terbahagi kepada dua jilid. Jilid pertama mempunyai 252 halaman dan jilid kedua 272 halaman. Perbincangan dalam kitab ini meliputi persoalan

67 Koleksi Manuskrip Dewan Bahasa dan Pustaka, DBP-K2175/12; $\quad$ http://ww1.utusan.com.my/utusan/info. asp? $\mathrm{y}=2006 \& \mathrm{dt}=1204 \& \mathrm{pub}=$ utusan_malaysia\&sec $=$ Bicara Agama\&pg=ba_01.htm\&arc=hive

68 Hujjah al-Balighah 'ala Jama'ah al-Mukhasamah, MSS 3575, MSS 3584 Pusat Manuskrip Negara, Perpustakaan Negara Malaysia, Kuala Lumpur.

69 Hujjah al-Balighah 'ala Jama'ah al-Mukhasamah, MSS 400, MSS 4077, Pusat Manuskrip Negara, Perpustakaan Negara Malaysia, Kuala Lumpur.

70 Sabil al-Muhtadin lil fiqh Umur al-Din, MS 554, Pusat Manuskrip Negara, Perpustakaan Negara Malaysia, Kuala Lumpur; Sabil alMuhtadin li al-Tafaqqah fi Amr al-Din, MSS 1135, Pusat Manuskrip Negara, Perpustakaan Negara Malaysia, Kuala Lumpur. 
ibadat berkaitan bersuci, solat, puasa, zakat, haji, akikah, korban, makanan yang halal dan haram serta sembelihan. ${ }^{71}$

Perbincangan mengenai ibadat adalah perbincangan yang kerap ditulis pada karya fiqh abad ke-18. Ia melibatkan ibadat asas untuk memberikan kefahaman awal kepada masyarakat Melayu yang ingin mempelajari dan memahami ajaran Islam. Ini kerana karya-karya fiqh yang ditulis oleh sarjana Islam hampir semuanya mempunyai kaitan rapat dengan hal ehwal kemasyarakatan. ${ }^{72}$ Dalam konteks penulisan karya fiqh Melayu abad ke-18 kebanyakan penulisan bersifat umum dan ringkas serta bahasa dan kalimah yang sukar difahami kerana terdapat pengaruh tulisan Jawi klasik. ${ }^{73}$ Teks dan kandungan lebih khusus kepada penulisan karya terjemahan, saduran, menyalin dan menulis semula apa yang telah ditulis dalam kitab-kitab klasik Arab. ${ }^{74}$ Boleh dikatakan

71 Wan Kamal Nadzif Wan Jamil, Mohd Zahirwan Halim Zainal Abidin \& Ahmad Fakhrurrazi Mohammed Zabidi, "Manhaj Syeikh Muhammad Arsyad al-Banjari dalam Penulisan Hadis: Tumpuan Kepada Kitab Jawi Sabil al-Muhtadin," (Kertas kerja, Seminar Serantau Ilmuan Hadith dalam Peradaban di Alam Melayu, 2010); Setiap perbincangan dalam bab ibadat khususnya dibincangkan dengan terperinci dengan perkara-perkara wajib, sunat, makruh dan sebagainya. Karya ini ditulis atas permintaan Sultan yang memerintah Banjar ketika itu. Ia dihasilkan untuk dijadikan panduan dan pedoman hukum serta dijadikan bahan pengajian di pondok-pondok seluruh Asia Tenggara; Muhamad Ismail Abdullah, "Mazhab Syafi'e dan Perkembangannya di Alam Melayu," kertas kerja dibentangkan di Kolokium Islam Pahang, Muzium Sultan Abu Bakar, Pekan, 2015, 8; Wan Kamal Nadzif Wan Jamil, Mohd Zahirwan Halim Zainal Abidin \& Ahmad Fakhrurrazi Mohammed Zabidi, "Manhaj Syeikh Muhammad Arsyad al-Banjari dalam Penulisan Hadis: Tumpuan Kepada Kitab Jawi Sabil al-Muhtadin."

72 Rahimin Affandi Abdul Rahim et.al., "Warisan Karya Ulama Melayu-Islam Silam dan Kaitannya dengan Pengajian Moral di Zaman Moden," Jurnal Usuluddin, vol. 27 (2008), 170.

73 Lihat Kang Keong Seock, Perkembangan Tulisan Jawi dalam Masyarakat Melayu (Kuala Lumpur: Dewan Bahasa dan Pustaka, 1993), 3-35

74 Ini dapat dilihat dalam penulisan karya fiqh Melayu pengarang menyatakan mereka menterjemahkan karya penulisan ini dari kitab tertentu; Fath al-Manan, MSS 21, Pusat Manuskrip Negara, Perpustakaan Negara Malaysia Kuala Lumpur, 1. 
tiada kecenderungan ijtihad dalam penulisan karya fiqh Melayu. Malah tidak wujud corak dan pola penulisan khusus seperti penulisan fatwa dan usul. Hasil penelitian, penulis mendapati tiada penulisan berkaitan ilmu usul fiqh dalam karya fiqh Melayu abad ke-17 dan 18.

Rasionalnya, penulisan karya fiqh Melayu mustahil dapat ditulis dan dihasilkan tanpa pengetahuan mendalam terhadap ilmu usul fiqh. Persoalan ini penting untuk diketahui kerana ilmu usul fiqh merupakan ilmu pemikiran intelektual umat Islam ${ }^{75}$ dan subjek penting dalam ilmu pengajian Syariah. ${ }^{76}$ Kandungannya membahaskan kaedah komprehensif dalam pengamalan proses ijtihad ${ }^{77}$ sebagai mekanisme istinbāt hukum yang diperlukan oleh para mujtahid. ${ }^{78}$ Ia juga berperanan menyediakan asas kepada pembinaan hukum Islam. ${ }^{79}$ Namun, abad ke-19 menyaksikan terdapat sedikit kecenderungan ijtihad dan usaha awal penulisan bercorak fatwa dalam karya fiqh Melayu. Penulisan fatwa dan usul dirintis oleh Syeikh Daud bin Abdullah al-Fatani dalam karya fatwa â fatāniyyah. ${ }^{80}$

Menurut Wan Mohd. Shaghir karya usul fiqh yang pertama ditulis di Alam Melayu adalah karya fath al-Manan ${ }^{81} 1834 \mathrm{M}$ yang ditulis oleh Syeikh Daud bin Abdullah al-Fatani. Dalam catatan muqaddimah Syeikh Daud telah menulis beberapa ayat berkaitan kaedah ilmu usul fiqh. Beliau menekankan untuk berhukum

75 Abdul Basith Junaidy, "Revitalisasi Usul Fiqh dalam Menghadapi Perubahan Sosial," Islamika, vol. 3, no. 2 (2009), 43.

76 Irwan Mohd Subri, "Penggunaan Masalah dalam Pembelajaran Subjek Usul Fiqh: Satu Kajian di Universiti Sains Islam Malaysia,” Jurnal Syariah, 15:1 (2007), 96.

77 Noor Naemah Abdul Rahman, "Pengajaran Kursus Usul Al-Fiqh Peringkat Ijazah Dasar Akademi Pengajian Islam Universiti Malaya: Pengalaman dan Penilaian," Jurnal Syariah, 14:1 (2006), 143.

78 Irwan Mohd Subri, "Penggunaan Masalah," 96.

79 Mohd Daud Bakar, "Usul Al-Fiqh Sebagai Kaedah Penyelidikan dalam Pengajian Syariah" dalam Dinamisme Pengajian Syariah, ed. Mahmood Zuhdi Ab. Majid et al. (Kuala Lumpur: Akademi Pengajian Islam Universiti Malaya, 2001), 37.

80 Fatwa Fataniyyah, Matba'ah Patani Press, $1377 \mathrm{H}$.

81 Fath Al Manan, MSS 121, MSS 233, Pusat Manuskrip Negara, Perpustakaan Negara Malaysia Kuala Lumpur: 
dengan dalil-dalil yang qat'ie dalam kaedah pengambilan hukum. ${ }^{82}$ Hasil penelitian dalam karya-karya fiqh Melayu penulis mendapati masih terdapat penulisan ringkas ilmu usul fiqh dalam karya fiqh Melayu. Meskipun penulisan ilmu usul dilihat ringkas, terdapat tulisan tentang qias, ijmak, maslahah, syarat berfatwa, kaedah fiqh, mahāsin syarīah, penghujahan al-Sunnah, ${ }^{83}$ namun ia masih kekal releven mengikut konteks zamannya. Bagi pendapat penulis, berkemungkinan apa yang dinyatakan oleh Wan Mohd. Shaghir adalah kaedah penulisan usul fiqh yang pertama ditulis di Alam Melayu. Ini kerana tiada perbincangan dan huraian khusus tentang ilmu usul fiqh dalam penulisan karya fath al-Manan. Perkembangan penulisan karya fiqh Melayu akhirnya membentuk penulisan bercorak pemikiran intelektual dan hukum merujuk kepada ilmu usul. Usaha ini dapat dilihat dalam perkembangan penulisan fiqh yang berkembang pada abad ke-20. Terdapat elemen dan unsur penulisan ilmu usul fiqh dalam karya tulisan

82 Wan Mohd Shaghir Abdullah, Penutup Perdebatan Islam Alaf Kedua di Dunia Melayu (Kuala Lumpur: Khazanah Fathaniyyah, 2010), 136; ووفقهم احكام اصول الدينية بالبناء على ادلة القطعية lihat Fath al-Manan, MSS 21, Pusat Manuskrip Negara, Perpustakaan Negara Malaysia, Kuala Lumpur.

83 Hujjah al-Balighah 'ala Jama'ah al-Mukhasamah, MSS 3575, Pusat Manuskrip Negara, Perpustakaan Negara Malaysia, Kuala Lumpur, 5-6; Hujjah al-Balighah 'ala Jama'ah al-Mukhasamah, MSS 3575, Pusat Manuskrip Negara, Perpustakaan Negara Malaysia, Kuala Lumpur, 6; Muhammd bin Ismail Daud al-Patani, Kitab al-Bahr alWafi wa al-Nahr al-Safi, cet.1 (Jeddah: Matba'ah al-Sharqiah, 1931), 170; Mir'ah al-Thullab fi Tashil al-Ma'rifat al-Ahkam wal Syari'ah li al-Mulk al-Wahhab al-kifayah MSS 2674, Pusat Manuskrip Negara, Perpustakaan Negara Malaysia, Kuala Lumpur, 225; Nahj al-Raghibin MSS 332, Pusat Manuskrip Negara, Perpustakaan Negara Malaysia, Kuala Lumpur, 
fiqh Melayu. ${ }^{84}$ Perbincangan yang dilontarkan bukan bermaksud ulama Melayu tidak mampu menulis karya-karya bermutu seperti karya usul fiqh pada peringkat awal penulisan fiqh. Penulisan dan pemahaman ilmu fiqh yang ditulis dan disebarkan oleh ulama Melayu terdahulu mustahil dapat disebarkan tanpa mereka memahami subjek usūl al-fiqh secara mendalam. Pemikiran usul mereka banyak dilontarkan di dalam tulisan figh yang diterjemahkan ke dalam karya-karya fiqh Melayu. Justeru itu, pemikiran dan pengetahuan usul fiqh memang telah diketahui oleh ulama dan sarjana Melayu ketika itu walaupun tidak dibukukan. ${ }^{85}$

Impak perkembangan karya fiqh Melayu yang ditulis zaman berzaman menjadikan pengembangan intelektual dalam masyarakat Melayu Alam Melayu. Apabila tercetusnya idea-idea penulisan dan pertumbuhan baru dalam penulisan fiqh Melayu maka ilmu usul fiqh mula dipelajari dan semakin berkembang. Ini dapat dilihat dalam perkembangan penulisan karya fiqh Melayu dalam penghasilan corak penulisan ilmu usul fiqh. Penulisan ilmu usul fiqh mula ditulis secara lebih terbuka dan berkembang pada abad ke-20. Pada peringkat awal penulisan tidak terdapat karya berkaitan usul fiqh dan buku-buku yang ditulis dan diajar oleh fuqaha Melayu. Sehinggalah perkembangan penulisan fiqh Melayu melahirkan karya usul fiqh ditulis walaupun ringkas, namun ia memperlihatkan kesan besar terhadap perkembangan penulisan karya fiqh Melayu. Tradisi perkembangan ini menyaksikan ilmu

84 Terdapat perbincangan berkaitan hukum yang merujuk kepada perbincangan ilmu usul seperti dalam karya Syeikh Muhammad Tahir Jalaluddin dalam kitab Ta 'yid Tadhkirah Muttabi ' al-Sunnah fi al-Rad 'Ala al-Qa'il bi Sunniyah Rak'atayn Qabl al-Jum 'ah; Surat Persendirian Syeikh Muhammad Tahir Jalaluddin, Ta'yīd Tadhkirah Muttabi' al-Sunnah fi al-Rad 'Ala al-Qa'il bi Sunniyyah Rak'atain Qabl al-Jum'ah, No Ruj: 2006/0036134 (1953), Arkib Negara Malaysia, Kuala Lumpur; karya Bahr al-Madhi tulisan Syiekh Muhammad Idris al-Marbawi. Walaupun karya ini dikenali sebagai karya hadis namun terdapat penulisan dan perbincangan berkaitan ilmu usul yang ditulis dalam karya tersebut.

85 Rahimin Affandi Abdul Rahim, "Pengamalan Ilmu Usul al-Fiqh di dalam Sastera Undang-Undang Melayu: Satu Analisis," dalam Kesusateraan dan Undang-Undang ed. Mohamad Mokhtar Hassan et al. (Kuala Lumpur: Akademi Pengajian Melayu, Universiti Malaya, 2003), 158-165. 
usul fiqh mula dipelajari dan ditulis oleh para fuqaha walaupun secara ringkas. Ilmu ini mula dibukukan oleh sarjana Melayu secara tersusun mengikut format displin ilmu. Ini dapat dilihat terdapat banyak karya-karya usul fiqh ditulis dan dikembangkan bermula pada abad ke-20. Antaranya karya penulisan al-Aqwāl al-Mulhaqah 'ala Mukhtașar al-Waraqah fì Usūl al-Fiqhiyyah. Karya ini ditulis oleh Syeikh Abdul Haq Bin Abdul Hannan alJawi al-Bantani. Dicetak oleh Mathba'ah al-Miriyah al-Kainah Mekah 1901M. Karya Lathāif al-Isyarāt ila Syarhi Tashīl alThuruqāh li Nazmi al-Waraqāh fi al-Usūl al-Fiqhiyyah 1908M. Karya ini dikarang oleh Syeikh Abdul Hamid bin Muhammad Ali bin Abdul Qadir al-Khatib. Terdapat berbagai-bagai edisi cetakan antaranya dari Mathbā'ah Dār al-Thaiba'ah Masrīyah. ${ }^{86}$ Antara penulisan karya ilmu usul fiqh terawal di Tanah Melayu ditulis oleh Ustaz Abdul Qadir Hasan dengan tajuk usül al-fiqh. Dicetak oleh percetakan Pustaka Aman Press Sdn. Bhd. Cetakan pertama adalah pada tahun $1973 \mathrm{M} \cdot{ }^{87}$ Hasil pemerhatian, penulis mendapati terdapat banyak penulisan karya usul fiqh pada awal dan pertengahan abad ke-20 di Alam Melayu. Ini membuktikan impak perkembangan karya-karya fiqh yang ditulis zaman berzaman menjadikan perkembangan penulisan ilmu usul fiqh dalam masyarakat Melayu berkembang berbanding sebelumnya tidak dipelajari dan dibukukan dalam disiplin ilmu.

Selain itu, kesan perkembangan penulisan karya fiqh Melayu yang ditulis zaman berzaman menjadikan pengembangan intelektual dalam karya pada abad ke-20 di Alam Melayu. Impak perkembangan dan pengaruh penulisan karya fiqh Melayu membentuk satu paradigma pemikiran yang tinggi sehingga lahir karya penulisan bentuk khiläfïyyah pada awal dan pertengahan abad ke-20. Pada awal abad ke-17 hingga ke-19 corak dan pola penulisan karya fiqh Melayu terikat dengan corak penulisan dari mazhab Syafi'e. Fuqaha Melayu hanya mengutip dan mengambil pendapat dari pendapat imam Syafi'e. Manakala pendapat yang kontradik dengan mazhab Syafi'e ditolak sama sekali. Isu-isu khiläfìyyah ini belegar sekitar ibadat berkaitan furuk fiqh akibat

86 Wan Mohd. Shaghir, Katalog Karya Melayu Klasik (Edisi Penyempurnaan) (Khazanah Fathaniyyah: Selangor, 2018), 32,37.

87 Abdul Qadir Hasan, Usul al-Fiqh (Kelantan: Pustaka Aman Press Sdn. Bhd. cet. 7, 1992). 
daripada perbezaan pandangan dan ijtihad. Malahan Alam Melayu antara abad ke-20 dan ke-21. Menurut Mohd Amin karya khilaffiyyah terawal di Alam Melayu ditulis oleh Syeikh Muhammad Tahir Jalaluddin. Penulisan bentuk khiläfiyyah perbincangan khiläfiyyah menjadi isu yang hangat diperbincangan oleh masyarakat Islam di mula ditulis pada tahun 1906-1908M di Semenanjung Tanah Melayu sedangkan di Indonesia bermula pada tahun 1911M. Manakala di Patani dan Thailand pada dekad 1960M.8 ${ }^{88}$ Terdapat beberapa karya khiläfizyah yang ditulis di Alam Melayu sekitar abad ke-20 antaranya karya İqua al-Manām ila Tharīqi Saiyid al-Anām. Karya ini ditulis oleh Muhammad Yasin Haji Abdul Ghani Minangkabau pada 1927M. Karya AtTahașșinah 'an Ittibā' al-Masāil al-Syuzuzīah. Karya ini ditulis oleh Syeikh Syamsuddin Gelar Soetan Radjo Endah pada 1928M. Sementara itu terdapat karya yang judul tajuknya dalam bahasa Melayu seperti karya Cahaya Suluh pada Menyatakan Jum'at kurang daripada Empat Puluh (M). Ianya ditulis oleh Muhammad Basiyuni Imran, Maharaja Imam Sambas pada 1920M. Karya al-Bāyan yang ditulis oleh Muhammad Fadhlullah Suhaimi al-Azhari pada tahun $1953 \mathrm{M}$ dan dicetak oleh al-Ahmadiyah Press pada tahun yang sama. Karya Cermin Suluhan ditulis oleh Muhammad bin Muhammad Shalih al-Kalantani. Karya ini dicetak oleh Matbā'ah Dār Thib̄a'ah al-Islāmīyah, Patani pada 1962M. Kesemua karya ini adalah karya khiläfìyyah yang tersebar dan diterbitkan pada awal dan pertengahan abad ke-20.

Hasil perbincangan, secara dasarnya penulis hanya membentangkan lima karya fiqh Melayu yang dianggap masyhur dan terpilih berdasarkan pengaruh dalam perkembangan penulisan karya manuskrip Alam Melayu. Pelbagai bentuk karya corak dan pendekatan penulisan ilmiah telah dikarang oleh para fuqaha Alam Melayu sebagai media penting untuk menyampaikan ilmu pengetahuan. Karya-karya ini muncul sebagai khazanah warisan yang bernilai tinggi penzamanan. Ia tetap dipelajari dan dijadikan

88 Mohamad Amin Abu Bakar, "Sumbangan Syeikh Muhammad Tahir Jalaluddin Al-Falaki Terhadap Perkembangan Fiqh dan Falak," (Tesis Ijazah Kedoktoran, Fakulti Pengajian Islam, Universiti Kebangsaan Malaysia Bangi, 2012). 
panduan masyarakat bukan sahaja di Alam Melayu malah turut dijadikan panduan dan kajian di peringkat antarabangsa. Ini jelas membuktikan bahawa karya ini mempunyai pengaruh dan nilai tinggi dalam bidang intelektual. Tidak dapat dinafikan sumbangan ulama dan sarjana Melayu dalam penghasilan karya fiqh Melayu. Antara tokoh-tokoh penulisan fiqh Alam Melayu yang masyhur dan ternama seperti Syed Hussain Jamaluddin al-Qubra, Hamzah Fansuri, Samsuddin al-Sumaterani, Nuruddin al-Raniri, Abdul Rauf Sinkel, Syeikh Yusuf al-Makasari, Syeikh Daud al-Fatani, Haji Wan Ahmad bin Muhamad Zain bin Mustafa al-Patani, Abdul Samad al-Palembani, Syeikh Ahmad Khatib al-Minangkabawi, Syeikh Muhamad Arsyad al-Banjari, Syed Abdul Kadir Kedah, Syeikh Abdul Malik Tok Pulau Manis, Terengganu, Haji Abdul Samad bin Muhamad Salleh al-Kelantani (Tuan Tabal), Muhamad Yusuf bin Ahmad al-Kenali (Tok Kenali), Syeikh Muhamad Idris Abdul Rauf al-Marbawi dan lain-lain lagi. Perkembangan penulisan dalam masyarakat Melayu ini mempunyai kaitan dengan budaya yang dibawa oleh ajaran Islam. Ia menjadikan masyarakat Melayu menjadi masyarakat yang berilmu selepas kedatangan Islam di rantau Alam Melayu. ${ }^{89}$

\section{UNSUR KEARIFAN TEMPATAN DALAM KARYA FIQH MELAYU}

Dalam perbincangan mengenai kearifan tempatan dalam penulisan karya fiqh Melayu persoalan utama yang perlu diberi perhatian bagaimana karya fiqh Melayu boleh dikaitkan dengan kearifan Melayu. Walaupun karya-karya fiqh Melayu dianggap di dalam dunia akademia sebagai karya intelektual namun sebenarnya ia adalah karya sintesis antara karya-karya Islam Timur tengah dengan kearifan tempatan Melayu Islam. Dalam disiplin penulisan dan pengkaryaan ilmu fiqh, terdapat ramai ulama yang menyumbang ke arah pembangunan kearifan tempatan dalam masyarakat Melayu Alam Melayu. Di antara mereka adalah Syeikh Muhammad Arshad al-Banjari, Syeikh Daud al-Fatani,

89 Mohd Puaad Abdul Malik \& Rahimin Affandi Abd. Rahim, "Kertas Kerja Kitab Jawi dan Pengilmuan Masyarakat Melayu," Seminar Antarabangsa Linguistik dan Bahasa Melayu, Hotel Perdana Kelantan, 6-7 Februari 2018. 
Syeikh Abdul Samad al-Falembani dan sebagainya. ${ }^{90}$ Karya-karya mereka memberi sumbangan besar dalam setiap aspek kehidupan dan masih menjadi rujukan di rantau Alam Melayu sehingga membentuk hubungan intelektual yang mementingkan ilmu pengetahuan berdasarkan budaya ilmu yang sejati. ${ }^{91}$ Kematangan penulisan karya fiqh Melayu abad ke-18 merangkumi kearifan dan metodologi ulama Melayu. Setiap pengkaji kitab Jawi memang akan terkesan dengan mutu ilmiah yang dimilikinya. Ia menepati kriteria karya ilmiah seperti mana difahami dalam konteks moden. ${ }^{92}$

Hal ini jelas boleh dilihat aspek kearifan tempatan dalam konteks intelektual, tulisan Jawi diperkenalkan semenjak abad ke-13 yang mana penulisan serta inskripsi Jawi adalah bercorak tempatan. Keadaan ini menyebabkan tulisan jawi berkembang seterusnya karya-karya Jawi mula ditulis. Apabila kita meneliti aksara dan sistem tulisan Jawi ianya memperlihatkan hasil

90 Fauzi Deraman, Karya-Karya Hadith dalam Tulisan Jawi, Jurnal Usuluddin bil. 7 (1998), 164-165; Mohd Anuar Ramli et.al., "Sumbangan Ulama Melayu Klasik, 178-185; Che Omar Awang, The Methodology of Teaching in Islam: With Special Reference to The Traditional Educational Method In Malaysia, Tesis Ijazah Kedoktoran, University of Edinburgh, 1996, 196-220; Wan Mohd. Shaghir, Wawasan Pemikiran Islam Ulama Asia Tenggara, jilid. 1. (Kuala Lumpur: Khazanah Fathaniyah, 2000), 36.

91 Wan Mohd Nor Wan Daud, Penjelasan Budaya Ilmu (Kuala Lumpur: Dewan Bahasa dan Pustaka, 1997), 108-109.

92 Terdapat perbezaan metode penulisan antara tiga abad awal 17, 18 dan 19. Metode penulisan abad ke-17 lebih menumpukan kepada penulisan konsep ibadat meliputi ibadat solat dan muamalat. Kandungan huraian dilihat ringkas kerana pendekatan penulisan zaman perkembangan dan penyebaran Islam Alam Melayu hanya memberi gambaran umum ajaran Islam kepada umat Melayu. Manakala penulisan abad ke-18 mencerminkan penulisan yang sedikit mendalam kepada persoalan ibadat dengan tajuk baru yang lebih kreatif. Manakala penulisan abad ke-19 lebih cenderung kepada bentuk teks pendalilan dalam ilmu fiqh. Antara dalil-lalil yang menjadi keutamaan adalah dalil al-Quran dan hadis yang menjadi pegangan yang dominan pada zaman itu. Di samping itu, terdapat tulisan pendapat ulama khususnya dalam mazhab Syafi'e ditulis secara ringkas serta dijadikan rujukan khusus dalam penulisan karya fiqh Melayu. 
kepandaian kearifan tempatan dan pemikiran orang Melayu disesuaikan dengan lidah dan sosiologi masyarakat Melayu. Dengan ilmu kearifan tempatan ilmuwan Melayu cuba mengenal pasti bunyi-bunyi dalam bahasa Melayu yang tidak terdapat di dalam aksara tulisan Arab. ${ }^{93}$ Ia sentiasa melalui proses semakan dan penambah baikan huruf-huruf Melayu yang disesuaikan dengan ejaan Bahasa Arab contohnya terdapat pada huruf qa dan nya yang tiada dalam ejaan bahasa arab. ${ }^{94}$ Kemampuan ulama Melayu terdahulu untuk menulis dan mengarang dalam karya fiqh Melayu lebih terserlah dengan bahasa dan ilmu pengetahuan Bahasa Melayu yang diperkayakan dalam bentuk tulisan Jawi yang dijadikan sebagai alat untuk memperkembangkan keilmuan Islam.

Di zaman pra Islam, masyarakat Melayu buta huruf dan sistem tulisan menjadi hak eksklusif golongan pembesar semata-mata. Penciptaan aksara jawi disesuaikan dengan kefahaman ulama Melayu awal tentang manusia sebagai homo sapien. ${ }^{95}$ Manusia memerlukan bahasa dan sistem tulisan khusus untuk tujuan komunikasi dan sistem tulisan jawi yang mengungkap idealism Islam. ${ }^{96}$ Ia menjadi wadah pencapaian dan penyebaran ilmu Islam. Wujudnya sistem tulisan sebagai mercu tanda kewujudan tamadun ilmu disesuatu kawasan. Ia menjadi medium untuk masyarakat menerima ilmu, mengungkap pemikiran dan mengaplikasikannya

93 Berhanundin et.al., Sejarah Tulisan Jawi dalam Pendidikan dan Dakwah di Terengganu (Kuala Trengganu: Penerbit Unisza, 2017), 22-23.

94 Syed Muhammad Naquib al-Attas, Islam dalam Sejarah dan Kebudayaan Melayu (Petaling Jaya: Angkatan Belia Islam Malaysia).

95 Homo sapien bermaksud manusia Melayu memerlukan komunikasi untuk hidup; Muhammad Kamal Hasan, Intelilectual Discourse at The End of the Second Millenium Concerns of a Muslim-Malay CEO (Kuala Lumpur, UIAM, 2001), 1.

96 Setelah Islam diterima secara meluas oleh masyarakat Melayu dan Bahasa Arab mula digunakan oleh masyarakat Melayu sebagai sistem tulisan mereka. Maka, penguasaan yang mendalam dalam Bahasa Arab menjadikan Bahasa Melayu mula menggunakan huruf Jawi; Adi Haji Taha et al., Manifestasi Tulisan Jawi (Kuala Lumpur: Kementerian Kebudayaan, Kesenian dan Warisan Malaysia, 2006), 30 . 
di dalam kehidupan. ${ }^{97}$ Idealisme pengarang karya fiqh melangkaui zaman dan maju kehadapan..$^{98}$ Memandangkan ia masih relevan dengan perbincangan di zaman sekarang meskipun jarak masa yang panjang kerana terdapat persamaan budaya iaitu budaya Melayu Islam. Ini jelas dibuktikan kerana terdapat karya fiqh Melayu masih dijadikan kajian akademik dan diajar di kebanyakan institusi pengajian seperti di masjid, pondok dan madrasah. ${ }^{99}$ Pemilihan teks timur tengah sebagai sumber asas karya fiqh Melayu tidak dilakukan secara terburu-buru dan sewenangwenangnya. Tetapi dipilih dengan akal ulama Melayu daripada bahan-bahan yang muktabar dan sesuai dengan sosiologi dan mentaliti budaya Melayu. Contohnya karya-karya timur tengah yang mempunyai ciri-ciri falsafah ditolak dan tidak diterima. ${ }^{100}$ Walaupun terdapat karya-karya sufi falsafah di kalangan dunia intelektual Islam Timur Tengah pada waktu itu ia tidak diterima dan dirujuk oleh ulama Melayu. Ini kerana mereka memahami kepentingan diterapkan mazhab ahl sunnah wa al-jamā'ah untuk wadah ilmu dan perpaduan ummah.

97 Hassan Madmarn, The Pondok and Madrasah in Patani (Bangi: Penerbit Universiti Kebangsaan Malaysia, 1999), 48-50.

98 Melalui penulisan fiqh, pemikiran dan paradigma ulama Timur Tengah berkaitan ilmu fiqh dipindahkan dan disebarkan kepada umat Islam di rantau Alam Melayu. Peranan karya fiqh ini menjadi pemangkin kepada terjadinya perubahan sosial dalam hal ehwal kehidupan masyarakat Melayu. Ia merupakan manifestasi kepada daya kemampuan dan intelektual ulama Melayu menulis dan menghasilkan ilmu. Selain itu, ia turut menyumbang kepada pembentukkan nilai intelektual dalam kalangan sarjana Melayu yang berusaha untuk memberikan sumbangan yang terbaik kepada masyarakat.

99 Bermula dihasilkan pada tahun 1871M hingga kini kebanyakan kitab Jawi dan karya fiqh Melayu masih disyarah dan diajar di masjid, surau, pondok dan halakah yang terdapat di seluruh pelusuk Alam Melayu; Shohana Hussin, Kitab Hidāyah al-Sālikīn Karangan alFalimbānī: Analisis Naskhah dan Kandungan," Jurnal Usuluddin 39 (2014), 72.

100 Faudzinaim Hj Badaruddin, "Peranan Kitab Jawi Tasawuf Sebagai Medium Transmisi Ilmu Islam kepada Masyarakat Melayu Alam Melayu," dalam International Journal of Islamic Thought, vol.1, 2012, 19-25. 
Antara ciri intelektual dalam penulisan kearifan tempatan karya fiqh abad ke-18 antaranya elemen integriti diambil kira dalam memastikan proses peniruan (plagiarism) tidak dilakukan dengan memetik kata-kata orang lain tanpa mengakuinya. Hal ini terdapat dalam penulisan karya fiqh Melayu apabila pengarangnya secara terangan menyatakan sumber rujukan ${ }^{101}$ pengambilan ideanya dalam penulisan karya fiqh. ${ }^{102}$ Bahkan ia menyatakan ia adalah hasil terjemahan kitab muktabar yang khusus. Ia bukannya terjemahan secara pasif tetapi ditokok tambah dengan pandangan pengarang berdasarkan realiti tempatan Alam Melayu. Ia juga mempunyai mukadimah, isi dan kesimpulan. Ia disusun dalam bentuk yang logik dan terbuka untuk diwacanakan. Buktinya karya fiqh mempunyai ruangan matan teks asal dan ruangan catatan/komentar pembaca. ${ }^{103}$ Kandungan perbincangan mengenai ilmu fiqh dilihat menarik seperti pengelasan judul kitab, bab, dan fasl merangkumi dari bab fiqh yang pertama hingga bab

101 Ini dapat dilihat dalam banyak penulisan karya fiqh Melayu antaranya; Diambilnya kata Ibn Hajar di dalam tuhfah yakni tiada dituntut; Nahj al-Raghibin MSS 332, Pusat Manuskrip Negara, Perpustakaan Negara Malaysia, Kuala Lumpur, 2; “...dan tiada harus mengerjakan sembahyang terawikh lebih dari dua puluh rakaat iaitu lima terawikh kerana tiap-tiap empat rakaat itu satu terawikh melainkan mengikut (amalan) ahli Madinah..."; Sabil al-Muhtadin lil fiqh Umur al-Din, MS 2252, Pusat Manuskrip Negara, Perpustakaan Negara Malaysia, Kuala Lumpur, 14; '...Inilah kesempurnaannya ma'rifah akan Allah SWT pada ahli Sunnah Wal Jamaah iaitu mazhab Imam yang empat iaitu Imam Syafi'e dan Imam Hanafi dan Imam Malik dan Imam Hanbali..; Hidayah al-Awwam MSS 3843, Pusat Manuskrip Negara, Perpustakaan Negara Malaysia, Kuala Lumpur, 4.

102 Sabil al-Muhtadin li al-Fiqh Umur al-Din, MS 555, Pusat Manuskrip Negara, Perpustakaan Negara Malaysia, Kuala Lumpur; pengarang menjelaskan pengambilan sumber rujukan dan idea penulisan penulisan.

103 Ciri-ciri penulisan fiqh ini boleh dilihat dalam karya penulisan fiqh abad 17, 18 dan 19; Tradisi mencatat/komentar menjadi amalan dalam penulisan karya Alam Melayu. Ini dapat dilihat dalam penulisan Tuan Minal dalam 'Aqidah al-Najin merupakan syarah daripada kitab Umm al-Barahin karangan al-Sanusi. Beliau menyatakan bukan hanya menterjemah karya tersebut malah turut menyelitkan komentar dan syarah kepada teks tersebut. 
terakhir ${ }^{104}$ dengan mekanisme penyusunan yang menarik. Ia melatih pembaca menjadi pembaca dan pemikir yang proaktif; membaca, memahami dan mencatat sekaligus. Lagipun, ia terbuka untuk dilakukan semakan dan komentar oleh pengarang yang lain. Kesemua usaha wacana ilmiah ini akan memastikan mutu kajiannya semakin baik.

Persoalan latar belakang masyarakat Alam Melayu diambil kira oleh ulama Melayu walaupun karya fiqh Islam Timur Tengah digunakan tetapi ia diadaptasi selari dengan realiti masyarakat Melayu. Contohnya dalam perbincangan binatang yang halal dan haram di makan menurut orang-orang tempatan Melayu. ${ }^{105}$ Ia dikaitkan dengan makanan yang boleh dimakan dan makanan yang tidak boleh di makan. Begitu juga dalam teks Syeikh Muhammad Arsyad al-Banjari beliau memasukkan perkataan Kalimantan atau Banjar seperti 'yangbinibini' 'wanyi' dengan mengambilkira dialek dan elemen tempatan dalam memilih bahasa tempatan sebagai medium pengembangan dakwah dan penyebaran Islam. ${ }^{106}$ Selain itu, karya fiqh Melayu juga merupakan teks ilmu yang amat penting sebagai wadah pendidikan masyarakat di rantau ini mengenai Islam. ${ }^{107}$ Melalui penulisan, transisi pemikiran, perbincangan

104 Sabil al-Muhtadin lil figh Umur al-Din, MS 554, Pusat Manuskrip Negara, Perpustakaan Negara Malaysia, Kuala Lumpur; fragmen kitab fikah, MS 687, Pusat Manuskrip Negara, Perpustakaan Negara Malaysia, Kuala Lumpur.

105 Kajian ini dihuraikan oleh Zurita Yusoff, "Kitab al-kifayah karangan Shaykh Abd al-Malik bin Abdullah: Teks dan Analisis" (Tesis Ijazah Kedoktoran, Jabatan Fiqh dan Usul, Akademi Pengajian Islam Universiti Malaya, Kuala Lumpur, 2014.

106 Omar Awang, "The Trengganu Inscription as the Earliest Known Evidence of the Finalisation of the Jawi Alphabet," Federation Museums Journal, 25, 1980, 55.

107 Ahmad Fauzi Abdul Hamid, Islamic Education in Malaysia (Singapore: S. Rajaratnam School of International Studies, 2010), 14. 
dan pandangan ulama-ulama ${ }^{108}$ berkaitan perbincangan hukum di Timur Tengah dipindahkan dan disebarkan kepada umat Islam di rantau Alam Melayu. Peranan karya-karya fiqh ini telah menjadi pemangkin penting kepada terjadinya perubahan-perubahan di dalam hal ehwal kehidupan masyarakat Melayu. Justeru, peranan penting karya fiqh Melayu terawal dapat dilihat secara umumnya membuktikan berlakunya proses pengajaran dan pendidikan dari sudut pemikiran hukum, penterjemahan dan penyelesaian hukum kepada masyarakat Melayu. Beberapa pendekatan ilmu juga diterapkan di dalam penulisan karya fiqh Melayu abad ke-18. Antaranya kandungannya sesuai dengan sifat orang Melayu yang baru memeluk Islam dengan penekanan kepada penulisan ilmuilmu ibadat fardu ain. Pendekatan yang diambil oleh pengarang karya fiqh dengan mengambil kira budaya dan sosiologi masyarakat Melayu dengan menerapakan kefahaman asas ibadat pada awal penulisan fiqh. ${ }^{109}$ Penggunaan hujah naqli sebagai asas dalil qat' $i$ dalam perbahasan hukum. ${ }^{110}$ Apabila perbincangan mengenai kefarduan sesuatu ibadat diberikan dalil hadis qudsi. Ini dapat dilihat dalam karya fiqh yang membincangakan asas kefarduan ibadat seperti bab solat dan juga di dalam bab ibadat yang lain. Penjelasan dan penghuraian untuk menerangkan maksud ibadatibadat di huraikan dengan lebih terperinci. Penggunaan bahasa yang mudah juga dalam penjelasan isu fiqh dengan memberikan takrif literal dan teknikal pada setiap istilah. Ia sebagai bahasa tulisan untuk dipermudahkan sesuai dengan khalayak pembaca.

108 Amir Fazlim Yusoff, "Pengaruh Ulama Timur Tengah Terhadap Penulisan Shaykh Muhammad Arsyad bin Abdullah al-Banjari dalam Kitab Sabil al-Muhtadin li al-Tafaqquh fi Amr al-Din," (Prosiding Nadwah Ulama Alam Melayu II: Sumbangan Ulama dan Tokoh Agama Borneo, Fakulti Pengajian Islam, Universiti Kebangsaan Malaysia, 2003), 39.

109 Penerapan kefahaman asas ibadat pada awal penulisan fiqh boleh dirujuk dalam karya Sirat al-Mustaqim dan Sabil al-Muhtadin li alTafaqqah fi Amr al-Din.

110 Hujjah al-Balighah 'ala Jama'ah al-Mukhasamah, MSS 3575, Pusat Manuskrip Negara, Perpustakaan Negara Malaysia, Kuala Lumpur, 4 . 


\section{KESIMPULAN}

Perkembangan dan pertumbuhan karya-karya fiqh Melayu abad ke-18 merupakan manifestasi kepada daya kemampuan, intelektual dan kearifan ulama menghasilkan sesuatu hasil penulisan fiqh. Ia menyumbang kepada pembentukkan nilai intelektual dalam kalangan sarjana Melayu yang berusaha untuk memberikan sumbangan yang terbaik kepada masyarakat. Walaupun asas penulisan karya fiqh pada peringkat awal dilihat ringkas, namun ia sesuai mengikut konteks masyarakat Melayu yang mula untuk memahami dan menerima Islam sebagai ajaran untuk dianuti. Dapat dirumuskan karya penulisan fiqh Melayu klasik mempunyai nilai perbincangan yang unggul dan unik dari sudut penulisan dan kandungan. Dari sudut perbincangan intelektual dianggap sebagai kearifan tempatan Melayu kerana ia terhasil daripada impak penyebaran Islam ke atas masyarakat Melayu.

\section{RUJUKAN}

'Ajjaj al-Khatib, Usul al-Hadith 'Ulumuhu wa Mustalahuhu (Jeddah: Dar al-Manarat, 1997).

Abd. Jalil Borham, "Sejarah Awal Penulisan dan Perlaksanaan Hukum Islam di Alam Melayu," Jurnal Syariah (1993), 146-152.

Abdul Basith Junaidy, "Revitalisasi Usul Fiqh dalam Menghadapi Perubahan Sosial," Islamika Islamika, vol. 3, no. 2 (2009), 43.

Abdul Hadi W.M, "Islam di Indonesia dan Transformasi Budaya," dalam Menjadi Indonesia: 13 Abad Eksistensi Islam di Bumi Alam Melayu ed. Komaruddin Hidayat dan Ahmad Gaus AF (Jakarta: Mizan, 2006), 470-471.

Abdul Kadir Haji Muhammad, Sejarah Penulisan Hukum Islam di Malaysia (Kuala Lumpur: Pustaka Salam, 1996).

Ahmad Misbah Muhamad Hilmi, et al., Mohd Faisal Mohamed, Nur Syahidah Abdul, Abdul Aziz Awang Kechik, "Manuskrip Hujjatul Balighah Karya Syeikh Jalaluddin Alasy: Kajian Tahqiq Teks Bab Pendakwaan," e-Jurnal Penyelidikan dan Inovasi, vol. III, no. 1 (2016). 
Ajidar Matsyah, "Jaringan Ulama-Ulama Melayu dalam Manuskrip, Seminar Serantau Kajian Manuskrip Melayu dan Kearifan Tempatan," Aceh, Indonesia, 2013.

Al-Kifayah, MS 517, Pusat Manuskrip Negara, Perpustakaan Negara Malaysia, Kuala Lumpur.

Al-Kifayah, MSS 1897, Pusat Manuskrip Negara, Perpustakaan Negara Malaysia, Kuala Lumpur.

Anwar Zainal Abidin, "Formasi Ulama Patani," dalam Ulama Patani Ketokohan dan Keilmuan, ed. Farid Mat Zin, et al. (Bangi: Penerbit Universiti Kebangsaan Malaysia, 2016).

Basrowi Sukidin, Metode Penelitian Kualitatif Persepktif Mikro (Surabaya: Insan Cendakia, 2006).

Berhanundin et.al., Sejarah Tulisan Jawi dalam Pendidikan dan Dakwah di Terengganu (Kuala Terengganu: Penerbit Unisza, 2017).

Faizuri Abdul Latif \& Faisal @ Ahmad Faisal Abdul Hamid, "Tradisi Penulisan Hadith Karya Ulama Melayu: Kajian Terhadap Kitab 'Aqidah al-Najin," Jurnal Usuluddin, bil. 30 (2009).

Fath al-Manan, MSS 21, Pusat Manuskrip Negara, Perpustakaan Negara Malaysia, Kuala Lumpur.

Fatwa fataniyyah, Matba'ah Patani Press, 1377 H.

Fragmen kitab fekah, MS 687, Pusat Manuskrip Negara, Perpustakaan Negara Malaysia, Kuala Lumpur.

Furu' al-Masail Wa Usul al-Wasail, MS 553, Pusat Manuskrip

Negara, Perpustakaan Negara Malaysia, Kuala Lumpur.

Ghayah al-Taqrib, MS 2384, Pusat Manuskrip Negara, Perpustakaan Negara Malaysia, Kuala Lumpur.

Hidayah al-Muta'allim Wa 'Umdat al-Mu'allim MS 4373, Pusat Manuskrip Negara, Perpustakaan Negara Malaysia, Kuala Lumpur.

Hujjah al-Balighah 'ala Jama'ah al-Mukhasamah, MSS 3575, MSS 3584, MSS 400, MSS 4077, Pusat Manuskrip Negara, Perpustakaan Negara Malaysia, Kuala Lumpur.

Idah al-Albab, MSS 2602, Pusat Manuskrip Negara, Perpustakaan Negara Malaysia, Kuala Lumpur. 
Idris Awang \& Tengku Sarina Aini Tengku Kasim, "Pembudayaan Mazhab Syafi'e dalam Masyarakat Islam di Malaysia," Jurnal Fiqh, no. 4 (2007), 157-172.

Irwan Mohd Subri, "Penggunaan Masalah dalam Pembelajaran Subjek Usul Fiqh: Satu Kajian di Universiti Sains Islam Malaysia," Jurnal Syariah, vol. 15, no. 1 (2007), 96.

Ismail. C.D. Tokoh-tokoh Ulama Semenanjung Melayu (1) (Kelantan: Majlis Agama Islam dan Adat Istiadat Melayu Kelantan, 2012).

Jamaludin, Saadan Man, Mohd Anuar Ramli, Mohammad Aizat, "Sumbangan Ulama Melayu Klasik dalam Menjana Budaya Ilmu di Alam Melayu," dalam Membongkar Rahsia Pendidikan Islam ed. Norarfan Zainal et al. (Brunei: Penerbit Kolej Universiti Perguruan Ugama Seri Begawan, 2012).

Koleksi Manuskrip Dewan Bahasa dan Pustaka, DBP-K2175/12 Kuala Lumpur.

Lexy J. Moleong, Metodologi Penelitian Kualitatif (Bandung: Karya Cv, 1993).

Mahayudin Yahaya, Islam di Alam Melayu (Kuala Lumpur: Dewan Bahasa dan Pustaka, 1998).

Makmur Harun, Firman \& Muhammad Yafri Yahya, Abms3203 Jawi dan Kajian Manuskrip Melayu, Buku Panduan Kursus Open University Malaysia (OUM), edisi Pertama, 2016.

Mir'ah al-Thullab fi Tashil al-Ma'rifat al-Ahkam wal Syari'ah li al-Mulkal-Wahhab al-Kifayah, MSS 1532, Pusat Manuskrip Negara, Perpustakaan Negara Malaysia, Kuala Lumpur

Mohd Anuar Ramli et al., "Sumbangan Ulama Melayu Klasik dalam Pembinaan Kearifan Tempatan di Alam Melayu," Jurnal Pengajian Melayu, vol. 27 (2016), 185-196.

Mohd Daud Bakar, "Usul Al-Fiqh Sebagai Kaedah Penyelidikan dalam Pengajian Syariah," dalam Dinamisme Pengajian Syariah, ed. Mahmood Zuhdi Ab. Majid et al. (Kuala Lumpur: Akademi Pengajian Islam Universiti Malaya, 2001). 
Mohd Puaad Abdul Malik \& Rahimin Affandi Abd. Rahim, Kertas Kerja "Kitab Jawi dan Pengilmuan Masyarakat Melayu," (Kertas kerja, Seminar Antarabangsa Lingustik dan Bahasa Melayu, Hotel Perdana Kelantan, 2018).

Mubarakfuri S.R, al-Rahiq al-Makhtum: Bahth fi al-Sirah alNabawiyyah (Tanta: Dar al-Bashir, 1987).

Muhammad Abu Bakar, "Pendirian dan Pembangunan: Islamisasi dan Isu-Isu Semasa dengan Rujukan kepada Tugas Generasi Ulul Albab dalam Abad Ke-21", dalam Islam dan Masyarakat Maju (Kuala Lumpur: Dewan Bahasa dan Pustaka, 1993), 39-48.

Muhammad Bukhari Lubis et.al., Tulisan Jawi Sehimpun Kajian (Shah Alam: Pusat Penerbitan Universiti (UPENA), 2006).

Muhammad Kamal Hasan, Intellectual Discourse at The End of the Second Millenium Concerns of a Muslim-Malay CEO, Kuala Lumpur, UIAM, 2001.

Najahudin Lateh et al., Tematik Emas dalam Karya Fiqh Ulama Alam Melayu: Tinjauan Terhadap Kitab al-Sirat alMustaqim, Furu' al-Masail dan Bahr al-Madhi" Seminar Serantau Kajian Manuskrip Melayu dan Kearifan Tempatan, 2013.

Noor Naemah Abdul Rahman, "Pengajaran Kursus Usul Al-Fiqh Peringkat Ijazah Dasar Akademi Pengajian Islam Universiti Malaya: Pengalaman dan Penilaian," Jurnal Syariah, vol. 14, no. 1 (2006), 143.

Nurdin AR, "Penggalian dan Inventarisasi 1000 Judul Naskah Melayu di Banda Aceh," Jurnal CMES, vol. X, edisi Julai (2017), 170-179.

Oman Fathurrahman, Filologi dan Islam Indonesia (Jakarta: Puslitbang Lektor Keagamaan, Kementerian Agama RI, 2010).

Omar Awang, "The Trengganu Inscription as the Earliest Known Evidence of the Finalisation of the Jawi Alphabet," Federation Museums Journal (1980). 
Portal Berita Utusan Malayisa, http://ww1.utusan.com.my/ utusan/info.asp?y=2006\&dt $=1204 \&$ pub $=$ utusan malaysi\&sec=Bibiccara_Agama\&pg=ba_01. htm\&arc=hivehttp://www.nu.or.id/post/read/76330/fiqihAlamMelayu-abad-ke-18-m-karya-faqih-jalaluddin-aceh

Portal Rasmi Perpustakaan Negara, http://www.pnm.gov.my/ index.php/pages/view/88, tarikh capaian 5 Disember 2016.

Rahimin Affandi Abdul Rahim et al., "Warisan Karya Ulama Melayu-Islam Silam dan Kaitannya dengan Pengajian Moral di Zaman Moden," Jurnal Usuluddin, bil. 27 (2008), 170-189.

Rahimin Affandi Abdul Rahim, "al-Quran dan Peranan Ulama Melayu dalam Pemodenan Rantau Alam Melayu" dalam Warisan al-Quran Peradaban Manusia ed. Mohd Radzi Othman et al. (Pulau Pinang: Universiti Sains Malaysia, 2005), 20-28.

Rahimin Affandi Abdul Rahim, Pengamalan Ilmu Usul al-Figh di dalam Sastera Undang-Undang Melayu: Satu Analisis, Seminar Kesusasteraan dan Undang-Undang, Kuala Lumpur (2001).

Rahmah Ahmad H. Osman Mohd Shahrizal Nasir, "Sastera Islam: Satu Perbandingan antara Pandangan Mohd Affandi Hassan dengan Abu al-Hasan Ali al-Nadwi," Jurnal e-Utama, vol. 3 (2011).

Sabil al-Muhtadin li al-Tafaqquh fi Umur al-Din, MS 554, Pusat Manuskrip Negara, Perpustakaan Negara Malaysia, Kuala Lumpur.

Sabil al-Muhtadin li al-Tafaqquh fi Umur al-Din, MSS 1135, Pusat Manuskrip Negara, Perpustakaan Negara Malaysia, Kuala Lumpur.

Sabil al-Muhtadin li al-Tafaqquh fi Umur al-Din, MSS 2252, Pusat Manuskrip Negara, Perpustakaan Negara Malaysia, Kuala Lumpur. 
Salsabil Haji Mohd Zain, Mustaffa Abdullah, Muhammad Alihanafiah Norasid "Penulisan Manuskrip Jawi di Alam Melayu: Satu Tinjauan Historis" dalam Islam dan Ketamadunan Melayu Sumbangan ke Arah Kemajuan Sejagat, vol. 1, ed. Mohd Roslan Mohd Nor \& Khadher Ahmad (Kuala Lumpur: Bahagian Penyelidikan dan Pembangunan, Akademi Pengajian Islam, Universiti Malaya, 2014), 236-237.

Shafie Abu Bakar, "Keilmuan Islam dan Tradisi Pengajian Pondok," dalam Budi Kencana (Kuala Lumpur, 1994), 9394.

Sirat al-Mustaqim MSS 3786, Pusat Manuskrip Negara, Perpustakaan Negara Malaysia Kuala Lumpur.

Sirat al-Mustaqim, MSS 144, Pusat Manuskrip Negara, Perpustakaan Negara Malaysia, Kuala Lumpur.

Sullam al-Mubtadi, MS 27, Pusat Manuskrip Negara, Perpustakaan Negara Malaysia, Kuala Lumpur.

Surat Persendirian Syeikh Muhammad Tahir Jalaluddin, Ta'yìd Tadhkirah Muttabi' al-Sunnah fial-Rad 'Ala alQa'il bi Sunniyyah Rak'atain Qabl al-Jum'ah, No Ruj: 2006/0036134 (1953), Arkib Negara Malaysia, Kuala Lumpur.

Syed Muhammad Naquib al-Attas, Islam dalam Sejarah dan Kebudayaan Melayu (Petaling Jaya: Angkatan Belia Islam Malaysia, 1990).

Wahidah, "Studi Naskah Fikih Melayu (Risalah Is'af al-Raghibin fi "Ilmi al-Faraidh) karya Jad Ahmad Mubarak," $A L$ BANJARI, vol. 19, no. 1 (2019), 25-48.

Wan Kamal Nadzif Wan Jamil, Mohd Zahirwan Halim Zainal Abidin \& Ahmad Fakhrurrazi Mohammed Zabidi, "Manhaj Syeikh Muhammad Arsyad al-Banjari dalam Penulisan Hadis: Tumpuan Kepada Kitab Jawi Sabil al-Muhtadin," (Kertas kerja, Seminar Serantau Ilmuan Hadith dalam Peradaban di Alam Melayu, 2010).

Wan Mohd Nor Wan Daud, Penjelasan Budaya Ilmu (Kuala Lumpur: Dewan Bahasa dan Pustaka, 1997). 
Wan Mohd Shaghir Abdullah, Penutup Perdebatan Islam Alaf Kedua di Dunia Melayu (Kuala Lumpur: Khazanah Fathaniyyah, 2010).

Wan Mohd. Shaghir Abdullah, Syeikh Daud al-Fathani Pengarang Ulung Asia Tenggara (Kuala Lumpur: Khazanah Fathaniyyah, 2018).

William Girdlestone Shellabear, Sejarah Melayu (Kuala Lumpur: Fajar Bakti, 1975).

Zurita Mohd Yusoff et. al., "Tok Pulau Manis: Pioneer of Fiqh Writings in the Malay Peninsular," Asian Social Science, vol. 11, no. 1 (2015), 87-89. 
Jurnal Fiqh, Vol. 17 No. 1 (2020) 89-134 